NBER WORKING PAPER SERIES

STRUCTURAL ADJUSTMENT POLICIES

IN HIGHLY INDEBTED COUNTRIES

Sebastian Edwards

Working Paper No. 2502

NATIONAL BUREAU OF ECONOMIC RESEARCH

1050 Massachusetts Avenue

Cambridge, MA 02138

February 1988

Prepared for the National Bureau of Economic Research Conference on Developing Countries Debt; Washington, DC, September 21-23, 1987. I have benefited from discussions with Marcelo Selowsky. I am grateful to Alejandra Cox-Edwards, Edgardo Barandiaran, Pari Kasliwal, Miguel Savastano, Jeff Sachs and the participants of the pre-conference meeting held in Cambridge in May 1987 for helpful comments. Financial support from UCLA's Academic Senate and from the National Science Foundation is gratefully acknowledged. The research reported here is part of the NBER's research program in International Studies. Any opinions expressed are those of the author and not those of the National Bureau of Economic Research. Support from The Tinker Foundation Incorporated is gratefully acknowledged. 
NBER Working Paper \#2502

February 1988

\section{Structural Adjustment Policies \\ in Highly Indebted Countries}

\section{ABSTRACT}

This paper deals with structural adjustment in the highly indebted countries. The origins of the debt crisis are first analyzed. Then the nature of the adjustment followed by the debt ridden countries between 1982 1987 is discussed. It is noted that for most nations the adjustment has been highly recessive. Next, the potential role of trade reforms in securing the resumption of sustained growth is analyzed.

Sebastian Edwards

Department of Economics

University of California, Los Angeles

405 Hilgard Avenue

Los Angeles, CA 90024 


\section{Introduction}

Mexico's announcement, in August of liri, that it couldn't any longer meet its international financial obligations took most of the world by surprise, sending shivers down the spines of bankers, politicians, and international bureaucrats. That fateful Friday the 13 th of August 1982 marked the beginning of the worst international financial crisis since the great depression. What initially was thought to be an isolated case of temporary illiquidity soon spread out to most of the developing world, placing the stability of the international financial system in serious jeopardy.

Five years after the eruption of the debt crisis most of the developing world is still struggling to get back on fts feet. Although the collapse of the world financial system predicted by some overly pessimistic observers has not materialized, the debt crisis is far from over. In fact, when traditional creditworthiness indicators, such as debt-exports or debtservice ratios are analyzed, the highly indebted countries are now in an even weaker position than in 1982 (see Table 1). It has now become apparent that a long term resolution of the debt problems will be a painful and protracted process, that will still require major additional adjustment efforts by the indebted countries, as well as extensive negotiations between debtor governments, creditor governments, the multilateral institutions and the banks.

The adjustment approaches followed until now by most of the highly indebted countries can best be described as emergency stabilization programs geared towards generating very large trade balance surpluses in very short periods of time. Given the new circumstances and the sudden halt in external financing after 1982, these countries had little choice but to use 
every possible tool at their disposal to achieve the needed turnaround in their current accounts. As a consequence the adjustment process has been quite costly, generating drastic declines in real income and important increases in unemployment. In fact, as is reflected in Table 2, in a number of Latin American countries in 1986 real per capita GDP was below its 1970 level!

A long run solution to the debt crisis problem would entail: (a) the regaining of creditworthiness by these countries, and thus the resumption of voluntary lending by the international financial community; and (b) the resumption of sustained growth. ${ }^{1}$ Much of the recent policy literature on the debt crisis has focused on these issues, with some of the discussion dealing with the type of long-run structural reforms the debt-troubled countries should implement in order to attain the dual objective of improved creditworthiness and growth. Most of this literature has recommended very conventional measures, that economists had been advocating for a long time prior to the debt crisis, including trade liberalization, financial reform, major devaluations, and a reduced role for the government. ${ }^{2}$ For example, this policy package is the core of the conditionality contemplated by the Baker plan. Surprisingly, there have been very few attempts to evaluate whether the design of these traditional policles, and in particular their speed and sequencing, should be altered in the presence of a major debt problem and, in some cases, still significant macroeconomic disequilibria.

The purpose of this paper is to analyze a number of issues related to structural adjustment in the highly indebted developing countries. The paper starts with a brief discussion of the main features of the adjustment process followed during 1982-87. It is noted that in spite of the major involvement of the IMF in this first phase of the adjustment, the actual 
policy packages implemented by most of the deh: troubled countries differed markedly from what we can describe as an orthodox IMF type stabilization program. It is argued that the "unorthodox" elements of the stabilization programs - such as the imposition of exchange controls and trade restrictions - - responded to the emergency nature of these programs. The paper then discusses at a more analytical level some longer term aspects of structural adjustment reforms, focusing on the relation between outward orientation, export promotion and trade liberalization. Emphasis is placed on the sequencing and speed of the structure reforms related to the external sector. Lessons drawn from the recent Southern Cone experiments with trade liberalization are incorporated into the analysis of the possible effects of tariff reforms on employment, income and growth. In that section the role of devaluations in structural adjustment processes is also discussed. Since the paper focuses on the role of the adjustment programs implemented by the countries themselves, relatively little emphasis is given to the role of banks and the international financial community.

II. The Nature of the Adjustment, 1982-1987

In this section we analyze the main features of the adjustment process followed by the highly indebted countries during 1982-87. ${ }^{3}$ Given the large diversity of experiences across countries it is not possible to make sweeping generalizations; in fact doing it would grossly oversimplify the discussion. When possible we point out the more important differences across countries.

\section{1 Origins of the Crisis}

During the second half of the 1970s and the early 1980 s most of the developing nations embarked on a foreign borrowing binge. Between 1975 and 
1982 the developing world's long term forelgn d, i, more than tripled, growing from $\$ 162.5$ billion to $\$ 551.2$ billion; in 1982 the total foreign debt of the developing world . - including short term debt and use of IMF credit .. stood at $\$ 738.7$ billions. Naturally, this huge increase in inclabtedness was made possible by the liberal way in which after the first oil shock in 1973, the international financial community and in particular the banks, provided funds to these countries. There is no doubt that the pace at which the developing countries were accumulating debt in the late 1970 s and early 1980 s - at a rate exceeding 208 per year - was not sustainable in the medium to longer run; some type of adjustment was bound to take place. The world, however, was shocked by the severity of the crisis; instead of seeing an orderly and slow reduction of the flow of borrowing a major crisis that brought capital flows to a virtual halt took place.

The causes behind the spectacular growth in borrowing during the 19741982 period varied from country to country. In Brazil, for example, itresponded to a deliberate development strategy adopted after the 1973 oil shock. This policy was based on import substitution supplemented with a heavy reliance on foreign borrowing to finance major investment projects. In Turkey, the accumulation of foreign indebtedness responded mainly to the rapid growth of the public sector, which used most of the funds for investment purposes. The situation was greatly aggravated by the existence of the so-called "convertible Turkish lira deposits," which provided a de-facto evergrowing subsidy to foreign borrowing. Contrary to most other countries Turkey entered into a crisis in 1977 , even before the second oil shock. In Mexico, the populist policies of the Echeverria and Lopez Purtillo administrations, with the spectacular growth in the public sector and in the fiscal 
deficit lay behind the crisis. The discovery of atditional oil reserves generated a wave of optimism that greatly influtuced the magnitude of the expenditure binge. It has been argued that approximately one half of the Mexican debt accumulated during the Lopez-Portillo administration went to finance capital flight (Buffie and Sangrines, 1987). In Chile, on the other hand, fiscal policies played no role in the unleashing of the crisis; most of the huge increase in Chile's foreign debt was contracted by the private sector with no government guarantees. The opening up of the Chilean economy, as part of the overall project of economic liberalization of the Pinochet government, allowed the private sector to finance huge increases in consumption -. especially of durables - - with borrowing from abroad. 4 In spite of their different experiences during the 1970s, in late 1982 all these countries faced a severe cut in foreign financing; they had come to share the harsh reality of the debt crisis. In the years to follow their experiences would again differ, as they tended to follow somewhat different adjustment programs.

The behavior of the world economy during the early 1980s, and in particular the increase of interest rates, the decline in commodity prices and the sluggish growth of the industrial countries, played an important role in determining the magnitude and timing of the crisis. ${ }^{5}$ A recent study by CEPAL has estimated that for the case of the Latin American nations the deterioration of unit prices of non-oil exports and the hike in world interest rates "explain" almost 50 percent of the increase in the region's current account deficit during 1981 and 1982.6

The magnitude of external shocks can be better understood by analyzing the evolution of the real interest rate "relevant" for these countries, computed as nominal LIBOR deflated by the rate of inflation of their 
exports. This concept of real interest rate combines in one indicator the effects of both the higher international nominal interest rates and of the lower commodity export prices. For the case of Latin America, this measure of the real interest rate jumped from an average of -3.48 during $1970-1980$ to 19.98 in $1981,27.58$ in 1982 and 17.48 in 1983. During the early 1980 s even those countries with a large percentage of their debt contracted at fixed concessionary terms experienced dramatic increases in their interest bi11. For example, as a result of the higher world interest rates, Cote d'Ivoire's interest payments increased from 3.1 percent of GDP in 1980 to more than 8 percent of GDP in 1983.

The adoption of inadequate exchange rate policies constitute one of the most important domestic causes of the crisis; most of the countries that eventually experienced payments difficulties allowed their real exchange rates to become highly overvalued during the late 1970 s and early 1980 s. $^{7}$ The case of the countries of the Southern Cone of South America are a primary example of inadequate exchange rate policies. In Chile, for example, after a period with a passive crawling peg, and as a way to bring down a stubborn inflationary process, the currency was fixed to the U.S. dollar in June of 1979, at the same time as wages were indexed to past inflation and capital controls were relaxed. As a result, the real exchange rate appreciated by more than 30 percent between 1979 and mid 1982, provoking a major deprotection of the domestic tradables sector and a gigantic current account deficit that exceeded 14 percent of GDP in $1981 .^{8}$ Argentina and Uruguay adopted a declining preannounced rate of devaluation, also as a way to reduce inflation. However, contrary to the case of Chile, in Argentina and Uruguay the predetermined rate of devaluation was clearly inconsistent with the magnitude of their fiscal deficit. This resulted not 
only in a substantial real appreciation, but also in a steady loss of credibility in the sustainability of the stabilization and liberalization programs, and in major capital flight. ${ }^{9}$

In Mexico, as a result of a highly expansive fiscal policy, which was coupled with a quasi-fixed nominal exchange rate, the effective real exchange rate experienced a real appreciation that exceeded 40 percent between 1976 and February of 1982. In 1976-77 in an effort to put an end to an acute situation of real exchange rate overvaluation, the Mexican peso was devalued by almost 80 percent relative to the U.S. dollar. By 1981 , however, the real value of the peso was already below its 1976 level; in less than 5 years more than 100 percent of the real effect of the devaluation had fully eroded. This case is particularly interesting since it clearly illustrates the difficulties that developing nations have many times faced when trying to engineer a real devaluation (see Edwards 1987).

The mismanagement of exchange rate policy was by no means a monopoly of the Latin American countries. For example, Cote d'Ivolre, the Philippines and Nigeria, among the highly indebted countries, also experienced important degrees of real exchange rate overvaluation during the period preceding the crisis. In both Cote d'Ivoire and the Philippines real appreciation exceeded 158 between 1978 and 1982, while in Nigeria it boarded 108 during the same perlod.

Not in every developing country, however, the exchange rate policy was inadequate. In Colombia, Indonesia and Korea, for example, the adoption of an active exchange rate management, including periodic devaluations, was an important component in overall strategies aimed at reducing the effects of world economic fluctuations. In that regard, Indonesia's exchange rate and macro policies were quite successful as a means to combat the Dutch-Disease 
effects associated with the oil booms. Also, Colombia's pragmatic approach towards exchange rate management allowed the country to avoid the deprotection effects of the coffee boom of $1975-79$ and to maintain a reasonable macroeconomic equilibrium. 10

Perhaps one of the most devastating effects of the generalized tendency towards overvaluation is that it fueled massive capital flight out of the developing world. In country after country, as it became increasingly apparent that the overvaluation was unsustainable in the longer run, the public began to heavily speculate against the central bank by acquiring foreign exchange and moving it abroad. Moreover, in some countries such as Chile and Argentina, the overvaluation casted doubts on the continuity of the overall development strategy based on liberalization and open markets. In Chile the public started to expect a hike in import tariffs and tried to anticipate it by acquiring imported durables in record quantities (Edwards and Edwards 1987). Although by its own semi-1llegal nature it is not easy to find official data on capltal flight, most available estimates coincide in suggesting that in most of the Latin American countries there was a significant increase in capital flight in the years surrounding the debt crisis. In a recent empirical study Cuddington (1986) has found that there is a significant relation between overvaluation and capital flight. Table 3 contains estimates on capital flight for six developing countries. There is an interesting contrast between the Latin American and the Asian nations. In particular notice that in Korea, a country that by and large avoided the temptation of real exchange rate overvaluation, between 1979 and 1984 capital flight was, on average, negative. 


\section{II.2 The Adjustment}

In August of 1982, immediately following Mexico's formal announcement that it was facing serious financial difficulties, the international financial community greatly reduced the amount of funds intermediated to the developing world. Even some countries, such as Colombia, which in no way faced payments problems, had serious macroeconomic disequilibria, or had accumulated debt at a very fast pace, were affected by this reduction in foreign lending. In fact, it is fair to say that the availability of foreign funds was reduced in a brutal way. For the developing world as a whole external financing was reduced by almost 40 percent between 1981 and 1983. Moreover, the major debtors were forced to fully close a current account deficit, that in 1982 exceeded $\$ 50$ billion in less than 3 years. By 1985 the aggregate current account had reached virtual equilibrium $(\$-0.1$ billion). In order to achieve this significant adjustment these countries had to engineer a major turnaround in their trade balance, which went from an aggregate deficit of almost $\$ 7$ billion in 1981 to a surplus of more than $\$ 40$ billion in 1984 . Table 4 contains data on exports, imports, the trade balance and the current account, that very vividly captures the magnitude of the adjustment.

As can be seen from Table 4 after reaching a record level in 1984 (almost $\$ 41$ billion) the aggregate trade surplus of the major debtors has experienced a steady decline and it is expected that in 1987 it will be less than $\$ 20$ billion. This rapid deterioration in the aggregate trade balance is to a large part a reflection of the Brazilian and Mexican situations.

Latin America was hit by the sudden drying up of loans in a particularly severe way. Table 5 contains data on the net transfer of resources to the region from 1973 to 1986. As can be seen, starting in 1982 the net 
transfer of resources became significantly negative; between 1982 and 1986 the annual net transfer averaged $-\$ 26.4$ billion, compared to a positive yearly average net transfer of more than $\$ 12$ billion between 1976 and 1971 . In real terms the net turnaround of resource transfers exceeded $\$ 70$ billion in the short period of 3 years between 1980 and 1983 !

These very rapid adjustments in the current account and trade balance were achieved in more than 100 percent by reductions in imports and in investment. As can be seen from Table 4 in the highly indebted countries the nominal dollar value of exports was lower in 1986 than in 1980 , with the magnitude of this decline exceeding 15 percent. This drop was basically the result of a decline in the prices of these countries exports of almost 25 percent between 1980 and 1986. In Latin America the deterioration of the terms of trade was so severe (see Table 6), that in spite of an increase in the quantum of exports of 30 percent between 1980 and 1986 , more than 100 percent of the net adjustment of the trade balance improvement has also been achieved via a reduction of imports.

For the major debtors as a group investment declined from an average of 26 percent of GDP in 1973.77 to an average of 17.2 percent in $1983-86$. Table 7 contains data on investment ratios for a selected group of countries. As can be seen with the exception of Chile, which started from an exceedingly weak position, in all of these countries the gross investment ratio declined significantly after the crisis, with the cases of Nigeria, the Philippines and Venezuela being particularly dramatic. In most cases public investment and investment in the construction sector were the components more severely curtailed. In the case of public investment this was a result of restrictive aggregate demand policies implemented immed. iately after the crisis. Naturally, this decline in investment has serious 
consequences for the prospects of renewed growth. Not only has the adjustment been costly in terms of current output and employment, but also in terms of future income.

Most countries faced the need to reverse the direction of the net transfers by resorting to a combination of expenditure reducing and expenditure switching policies, including devaluation, the imposition of capital controls and impore quotas. The adjustment required both a significant increase in real interest rates as well as major relative price changes or real devaluations. In most cases the selection of policy packages was based on the perceived "effectiveness" of these policies in the short run, rather than on efficiency, income distribution, or welfare considerations. As a result of the efforts made to implement rapidly effective policies a number of tradeoffs between different objectives -. including improvement in the current account and inflation .. emerged during the process.

In most countries the expenditure reducing policies have been centered on efforts to cut public expenditure. In a number of cases the reduction of real public expenditure has in fact very significant, with most of the cuts concentrating on public investment and government employees wages. According to CEPAL in Argentina, Ecuador, Mexico, Uruguay and Venezuela government expenditure was cut by more than 208 in real terms following the crisis. 11 Similarly, in Morocco real expenditure of the central government declined by 18 percent between 1982 and 1984, while in the Philippines this reduction exceeded 258 between 1982 and 1985.12

In spite of the effort to reduce overall public expenditures, government interest payments on the domestic and foreign debt increased quite significantly during the first five years of the adjustment process. This was a result of both the real devaluations engineered as part of the 
stabilization programs and of the deliberate policy of raising domestic interest rates in an effort to further curb aggregate expenditure. The negative effects of the devaluations on the interest bills of different governments are a good illustration of the tradeoffs involved in the adjustment process. In the majority of the major debtors most of the foreign debt is owed by the government .. either because the public sector originally contracted it, or because it took over it when the local private banking system collapsed, as in Chile. ${ }^{13}$ what real devaluations do is raise the (real) domestic currency cost to the government of raising the required funds to pay the interest bill. This effect has been significant in countries like Argentina, Mexico and Peru where interest payments on public sector foreign debt are a high proportion (i.e., approximately 208) of total govermment expenditure. ${ }^{14}$ In a number of countries .. most notably in Argentina and Chile -- the exchange rate policies followed during this period also became an important source of government expenditures. For example, in Argentina, the need to cover the exchange rate guarantee after the abandonment of the "tablita" generated staggering fiscal outlays. Similarly the adoption of a preferential (lower) exchange rate for foreign currency debtors in Chile resulted in an implicit subsidy that absorbed large amounts of foreign resources. 15

In spite of the relatively successful efforts to reduce public expendi. tures, fiscal deficits increased in relation to the pre-crisis period in the major debtors as a group (see Table 8). This was mainly due to the fact that in many of these countries total tax revenues were negatively affected by the recessions that followed the crisis. The steep increase in interest rates that took place in most countries also impacted negatively the fiscal accounts, via its effect on the public sector domestic debt. Moreover, in 
most cases the sources of fiscal deficit financing were affected by the crisis. Up to 1982 in most instances the public sector deficits were financed by foreign borrowing. The drying up of this source of funds forced the local governments to turn to the inflationary tax and to issuing additional domestic public debt.

The need to use inflationary financing placed pressure on the monetary and domestic credit policies which became significantly more expansive than what the IMF, the World Bank and the private bank officials felt they should have been. Table 8 contains summary data on monetary policy, the fiscal deficit and the average rate of inflation in these countries. These data quite clearly illustrate some of the most interesting features of the emergency phase of the adjustment process. As is pointed out in more detail below, contrary to the historical experience with IMF sponsored programs, these have been stabilization programs with acceleration in monetary expansion, persistent high fiscal deficits that largely exceed the levels that prevailed before the crisis, and very high inflation.

The restraint of wage increases was, in most countries, another major component of the expenditure reducing package. Table 9 contains data on the evolution of real wages in selected Latin American countries. As can be seen, with the exception of Argentina, Brazil and Colombia, the decline in real wages has been significant.

In most countries the adjustment also relied on higher real interest rates, which helped keep expenditure, and in particular investment, in check. It should be noted, however, that in some cases the rise in real interest rates began some time before the "official" unleashing of the debt crisis in August of 1982. For example, in the countries of the Southern Cone real interest rates began to quickly climb in mid-1981 as these 
economies were becoming clearly overheated; higher interest rates were in fact an early sign that in these countries the need for adjustment was quickly approaching. In Argentina the annual real lending rate already reached 19.38 in 1981 , significantly higher from the average of 1.58 prevailing during 1978-1980. In 1982 and 1983, as the effects of the debt crisis per se were being felt, the real lending interest rates remained high (around $12 \%$ per annum) but not as high as the level attained in 1981. Chile presents a similar case, as in 1981 the annual real interest rate reached 58.18, much higher than the average of the previous two years (8.58). During 1982 and 1983 the real lending rate declined to the still remarkable level of 168 per annum (Ramos, 1986).

Although in the Southern Cone real interest rates began climbing almost a whole year before August 1982, the debt crisis further shocked the already weakened financial sector. In particular, in Chile the halt of capital inflows was partially responsible for the timing and magnitude of the financial debacle of late 1982 and 1983. By the end of 1982 the foreign debt of the Chilean banking system exceeded US\$6.6 biliion, a remarkable figure when compared to the mere US $\$ 0.6$ billion of debt in 1978 ! These funds had been obtained without any government guarantee and had mainly been used to finance the operations of the large private conglomerates - - the socalled groups. By mid-1982 a large proportion of these loans were in fact bad-loans, since due to a number of factors including the real overvaluation of the peso, the grupos were facing very difficult financial times. During 1982 the amount of foreign funds avallable to the Chilean banks was reduced by more than 75 percent, generating a fatal blow to the troubled financial sector. As a result of these difficulties, in January 1983 the government stepped in, liquidating two banks and nationalized others. Responding to 
pressures by the international banks the Chilean government decided to take over these banks' foreign debt, guaranteeing now its payment. Paradoxically, at the end of 1983, the Chilean financial sector was in some way at the same juncture as it had been ten years before, in the midst of the Allende socialist government. It had been nationalized and was tightly controlled by the state (see Diaz Alejandro, 1985 and Edwards and Edwards, 1987).

After August of 1982 most countries also relied on expenditure switching policies; these consisted in most cases of a combination of nominal devaluations and, at least initially, of a major escalation in the degree of trade restrictions.

The extent of the devaluations varied from country to country being particularly severe in Latin America. In an effort to assure that the effects of the nominal devaluations on the real exchange rate didn't erode via inflation, most countries adopted some kind of active exchange rate management where the exchange rate continued to be adjusted after the initial parity change. In fact, as of July of 1986 out of the 15 major debtors 12 had some sort of crawling peg regime consisting of periodical adjustments of the nominal rate somewhat related to the differential between internal and external inflation.

Another important feature of the exchange rate policy followed by many countries was the adoption of multiple exchange rates. This basically served three purposes. First, by implementing differential exchange rates for capital and current account transactions . as in Venezuela - the authorities hoped to separate real transactions from the supposedly volatil. ity of capital movements. More importantly, howevtr, by imposing a free floating exchange rate on unregistered capital flows the Venezuelan 
authorities tried to discourage capital flight without greatly affecting the current account. Second, multiple rates were also applied as a way to supplement the protective system. Indeed, when different exchange rates are applied to different commercial transactions, the resulting outcome is perfectly equivalent to a differentiated tariff schedule. This practice was again used by Venezuela, as well as by Mexico. And third, in some councries, such as Mexico, Chile and Venezuela a lower "preferential" exchange rate has applied to the private sector repayment of foreign debt. The rationale for this preferential rate was that in this way it would be possible to avoid a the general bankruptcy of the private sector -. which had heavily borrowed from foreign banks at the previously fixed nominal exchange rate.

Most countries were able to generate important real devaluations, which in some cases more than corrected the overvaluation that preceded the crisis. In Turkey, for example, between 1982 and 1986 there was a 248 real effective devaluation, while in the Philippines the real devaluation amounted to more than 88 . It was however in the Latin American countries that the more important turnarounds of real exchange rate behavior were achieved. As can be seen in Table 10, in all of these countries the real effective exchange rate index shows that there have been significant real depreciations between 1982 and 1986.

As a result of these large nominal devaluations most countries experienced important increases in their price levels. As noted above, in an effort to avoid the erosive effects of these price increases the Central Bank authorities decided to resort to further devaluations as a means to maintain a high real exchange rate. Naturally this practice added fuel to the already accelerated rates of inflation (see Table 11). 
Immediately following the crisis in many (but not all) of the major debtors the devaluation policies were supplemented by the imposition of trade restrictions. Table 12, for example, presents data on some of the policles implemented by four countries.

An important question is whether the use of quantitative restrictions (QRs) instead of tariffs or more substantlal devaluations, during the initial phases of the adjustment has introduced unduly high costs in terms of growth and efficiency. A well known proposition in the theory of commercial policy is that, in terms of welfare and income distribution, tariffs are generally superior instruments than quotas as a means to restrict trade. ${ }^{16}$ That type of analysis, however, is static and assumes perfect information on behalf of the authorities; according to this simple setting the relevant elasticities are known and thus it is possible to compute the exact height of the desired tariff. In reality, however, things are quite different, since elasticitles magnitudes are only known in a very imprecise way. This means that in order to achieve a certain volume of imports with the use of tariffs, it is necessary to go through a trial and error process. This type of procedure may be very ineffective in cases such as the debt crisis where the foreign exchange value of imports has to be reduced very quickly, and where there are high penalties associated with surpassing that (much reduced) level of imports. For a small country that faces given forelgn currency prices of imports, the use of quotas is an effective way of being sure that the value of imports (in foreign exchange) will not exceed a certain level. As long as countries need to establish credibility regarding their willingness to adjust, it is particularly important not to surpass the preestablished level of imports. 
Although there is some justification for the (very) short term use of QRs in the very first phase of the adjustment, there are no good reasons for maintaining their use for long periods of time. From efficiency, fiscal as well as income distribution perspectives in the case of the recent debt crisis the maintenance of QRs for a long time have well known undesirable effects. For example, Buffie and Sanguines (1987) have argued that the generalized use of QRs in Mexico in 1982-1984 resulted in an unnecessary reduction of imports of intermediate inputs, greatly hurting the Mexican economy.

In some countries the extent to trade restrictions has recently been somewhat relaxed, while others have announced some easing up in the near future. In Chile, for example tariffs were reduced to a 20 uniform level. Mexico has taken some steps towards reducing the coverage of licenses, while in Bolivia as part of the stabilization program aimed at stopping hyperinflation quotas have been abolished and tariffs reduced. As is discussed in more detail below, in many countries trade liberalization packages are being discussed as a part of conditionality agreements with the multilateral institutions.

In spite of the significant efforts to adjust made by most of these countries - - and of the costs incurred in the process - the magnitude of their trade surpluses has systematically fallen short of their interest payments. In Latin America, for example, in 1986 the interest bill amounted to 5.38 of GDP while the trade surplus reached 2.3 percent of GDP. In most countries up to this point this financing gap has been closed, usually after long and protracted negotiations, by packages of funds provided by the banks and the multilateral institutions. It is important to notice, however, that the banks have been able to significantly reduce their exposure to the major 
debtors in spite of the fact that they have made some contributions to financing these funds shortfalls (see World Economic Outlook, April 1987).

Up to now banks have relied on the policing activities of the multilateral institutions, and in particular of the IMF, for determining whether a particular country is making a "sufficient" effort to adjust. A question that is still unresolved is whether the banks will make a serious commitment to providing additional financing to the indebted countries in the next few years.

A number of studies have suggested that for the great majority of the highly indebted countries it would not be possible to generate in the short run trade surpluses of a sufficient magnitude as to cover interest payments without further decreasing the level of real consumption. Selowsky and van der Tak (1986), for example, have estimated that a "typical" major debtor would need additional financing for approximately 5 years in order to experience some recovery in real consumption (28 per year) and in real income (48 per year). Under these assumptions, since the rate of growth of income exceeds that of consumption, domestic savings rise continuously. According to this simulation exercise after 5 years "the typical" major debtor would start to amortize its debt. After 6 more years the debt would have been reduced to "normal" levels, and the country would again be "creditworthy". Cline (1987) has recently argued, along similar lines, that banks could and should indeed increase the amount of funds being intermediated to those countries that show progress in their adjustment efforts.

\section{3 Crisis Adjustment and Traditional Stabilization Programs}

The above discussion shows that, in spite of the active involvement of the International Monetary Fund, the programs followed by most of the major debtors between 1982 and 1986 differed in a number of key respects from the 
typical IMF sponsored program of the pre-1982 era. These differences mainly involve the selection of policy packages, as well as the availability of additional financing. Also, the behavior of the exogenous variables, including the international environment, have tended to differ from the historical experiences.

According to Khan and Knight (1985), in the typical IMF program we can distinguish a macroeconomic and a structural adjustment component. The macro or demand management package is mainly based on restrictive monetary, fiscal and domestic credit policies, aimed at eliminating the disequilibrium between aggregate demand and aggregate supply, improving the current account and reducing inflation. Special emphasis is usually placed on the control of fiscal deficits. The structural adjustment or resource reallocation package, on the other hand, usually includes three main policy blocks: trade liberalization; (2) financial reform; and (3) major devaluation including exchange rate unification in the case of multiple rates. ${ }^{17}$

The objectives of the structural adjustment component of conventional programs is to increase efficiency, raise investment, and enhance growth opportunities. Historically, for most countries the implementation of IMF sponsored programs has not taken place at the same time as a gigantic foreign debt is being serviced. Quite on the contrary, it has usually been assumed that while implementing the structural reforms, these countries can command significant additional net funds from abroad (see khan and Knight, 1985). Although this may have been the case in the past, it is very far from today's reality, when the highly indebted countries have to generate a significant net transfer of resources to the rest of the world.

In terms of outcome a historically "successful" IMF program can be described by a reduced fiscal deficit, lower inflation, more liberalized 
trade, and an improvement in the current account and balance of payments. In many ways the current $(1982-86)$ adjustment looks very different from this IMF blueprint. Generally speaking, and as is captured by Tables 8 and 11 , this has been an inflationary adjustment process with high and persistent fiscal deficits. Additionally there has been an escalation in the degree of distortions of the external sectors, with a profusion of QRs and multiple exchange rates.

The behavior of investment has also been very different during the current crisis adjustment period when compared to the historical episodes. In a detailed study of 39 historical episodes of structural adjustment programs between 1962 and 1982 Edwards (forthcoming) found that for the group as a whole the investment ratio didn't experience a significant decline in any of the four years following the implementation of the programs. Moreover, according to this study, on average, in these historical episodes it is not possible to detect, as in the current case, significant declines in real output.

To a large extent the "unorthodoxy" of these new stabilization and adjustment programs can be attributed to three main factors: (a) the magnitude of the adjustment required; (b) the urgency with which it had to be implemented; and (c) the global nature of the crisis. In a way, when faced with the tradeoffs between current account corrections, efficiency of the adfustment and inflation these countries opted -. or were forced to opt - for the current account improvements placing, at least during the initial phases of the process, little priority on inflation, efficiency, or costs of the process. Implicitly the IMF endorsed or encouraged these adjustment programs, in spite of the fact that they departed from its traditional view. Now, however, as things are somewhat under control more emphas is is indeed 
being placed on efficiency, growth and other social costs. These issues are discussed in more detail in Section III.

\section{Trade Liberalization and Adjustment With Growth}

The emergency packages implemented until now have succeeded in averting what some considered to be an almost sure collapse of the world financial system. This has been achieved, however, at a significant cost for the major debtors in terms of decline in employment, income, and standard of living. The key question now is how to move from the current situation towards what we can call phase 2 of the adjustment process - a phase characterized by adjustment with growth. At a more concrete level, the Baker and the Bradley plans, among other initiatives, clearly reflect the preoccupation of politicians with this issue.

A number of authors $\cdots$ and indeed the supporters of the Baker plan, as well as the IMF - - believe that a rapid trade liberalization, coupled with devaluation, privatization, and financial reform, is the most reasonable strategy to achieve these objectives. ${ }^{18}$ For example, Balassa et al. (1986, p. 88) have recommended that, among other things, the developing nations should eliminate all QRs and reduce, in a period of 5 years, imports tariffs to a uniform 15 to 20 percent level; these tariff reforms should be coupled with significant devaluations, in order not to "deprotect" the tradables good sectors. 19 To a large extent these recommendations are very similar to what many economists have been advocating for many years for the developing countries. However, these new proposals are more drastic, in the sense of arguing for a bolder movement towards free trade. The current proposals on signiflcant trade liberalizations have not entered into a detailed discus. sion of the important issues related to strategy, including the appropriate 
speed and sequencing of reform. Also, there has been little consideration on the possible short run tradeoffs between these liberalization reforms aimed at improving efficiency and other objectives of the overall programs. Most of the traditional literature on trade liberalization has assumed that these reforms take place in the absence of a foreign debt overhang problem. Moreover, many writers have assumed that during the trade reform process countries will be able to attract substantial voluntary lending. Mckinnon (1973, 1982), for example, has forcefully warned us of the dangers related to excessive capital inflows during a trade liberalization episode. However, it is clear that at the present time, in the vast majority of LDCs there is very little danger of trade liberalization attracting excessive (or indeed any) voluntary capital inflows. Today, the problem is quite the opposite: countries have to generate a positive resource transfer to the rest of the world.

The purpose of this section is to analyze some specific issues related to trade reforms. We first discuss the relation between outward orientation, trade liberalization, and export promotion. We then analyze issues related to the order and speed of reforms, focussing on the relation between stabilization policies and trade reforms and on the unemployment effects of liberalization. Finally we deal with the role of devaluation and of credibility during a structural adjustment process.

\section{1 Outward Orientation. Export Promotion and Trade Liberalization}

There is by now an impressive amount of empirical evidence suggesting that countries that have adopted outward oriented development policies, that emphasize export promotion, have outperformed those countries that have followed inward oriented strategies based on import substitution. Even CEPAL - not exactly known for its endorsement of outward policies . has 
recently recognized that the excesses of import substitution have been very costly for Latin America; some of its senior staff members have recommended that in the future export promotion should play a more central role in that region's development policies. 20

There seems to be relatively less agreement, however, on whether "trade liberalization" packages have played an important role in the performance of the outward oriented economies. For example, in a recent paper Sachs (1987) questioned the idea that trade liberalizations are indeed a required component of successful outward oriented strategies. Making reference to the experiences of the East-Asian countries -- Japan, Korea, Singapore, Taiwan, and Hong Kong - Sachs argues that these countries' success was to a large extent due to an active role of government in promoting exports in an environment where imports had not yet been fully liberalized, and where macroeconomic (and especially fiscal) equilibrium was fostered. Whether one agrees with Sachs depends on how outward orientation, export promotion and trade liberalization are defined. Recently some confusion has emerged regarding these concepts, and it is not exactly clear what people mean by them.

In the more traditional policy literature of the 1960 s and 1970s trade liberalization was defined in a very general way; what economists usually meant was some relaxation of trade and exchange controls. In fact, in the by now classical NBER study on trade regimes directed by Bhagwati and Krueger a liberalization episode was defined as a more extensive use of the price mechanism that would reduce the anti-export bias of the trade regime. $^{21}$ In her 1985 review article on the problems of liberalization Krueger went as far as saying that even a (real) devaluation in the presence of QRs constituted a liberalization episode. These are indeed very mild 
defintions of liberalization. In fact today very few people will raise an eyebrow about them. Only recently has "trade liberalization" acquired a more drastic connotation, meaning (for many people) an elimination of QRs coupled with a severe reduction of import tariffs to a uniform level of around 10 percent. Moreover, recently trade liberalization has, in many ways, become synonymous of free market oriented policies with minimum or no government intervention at any level. 22

The difference between the old and new definitions of "trade liberalization" is, to a large extent, one of degree or intensity. While a devaluation in the presence of $Q R s$, or the replacement of $Q R s$ by (quasi) equivalent tariffs is a mild form of liberalization, the reduction of tariffs (with no QRs) to a uniform $10 \%$ or, for that matter, the complete elimination of tariffs is a very drastic liberalization. In order to clearly understand the different issues involved in policy discussions it is, then, crucial to specify the intensity of liberalization we are referring to. Unfortunately this is not always done; the policy literature on the subject is plagued with imprecisions and ambiguities.

There is little doubt that a successful export promotion policy requires some kind of trade liberalization. In fact, the historical evidence clearly shows that those countries that have successfully embarked on that kind of strategy have had a more "liberal" trade regime than those countries following indiscriminatory import substitution. The successful outward oriented countries have generally had lower coverage of prior licenses systems, lower average tariffs, less dispersion in their tariffs and less episodes of real exchange rate overvaluation. 23

In a recent major multi-country study by the World Bank it was found that there was a clear relation between movements towards more liberal trade 
systems - - although most countries still retained a number of controls -and a higher performance (Michaely, Choksi and Papageorgiou, 1986). In that regard, the case of Korea - one of, if not the most successful of the export-oriented countries .. is very educating. In 1985, for example, 908 of Korean imports were subject to automatic approval (i.e., were not subject to any form of QRs) and the average tariff rate was only 268 . Moreover, the tariff structure was characterized by higher tariffs concentrated on final goods, with capital equipment and intermediate inputs having relatively low degrees of protection. 24 This extent of import protection was significantly below that of most of the developing nations and also below the degree of Korean protection in 1965 , before the outward oriented policy was embraced. The Korean experience of export promotion coupled with trade liberalization can be contrasted with the Chilean case. Between 1975 and 1979 a drastic trade liberalization that eliminated all QRs, and reduced tariffs to a uniform 108 in four years was implemented in Chile; in addition, as part of a massive move towards free market orientation, this period's policies almost completely eliminated the government's role in defining external sector strategles. By allowing the real exchange rate to slip by approximately 308 between 1979 and 1982, the Chilean experience of that period became one of ultra trade liberalization without export promotion (see Edwards and Edwards, 1987).

Within the Latin American context Colombia after 1967 provides another educating example of successful export promotion-cum- some trade liberalization. Until that year the Colombia external sector was highly distorted and had been subject to deep and recurrent crisis; coffee exports provided most foreign exchange, and the Colombian economy was subject to the vagaries of the world coffee market. In 1967 three major measures were taken. First, 
any attempt to $\mathrm{fIx}$ the exchange rate was abandoned, and a crawling peg system aimed at avoiding real exchange rate overvaluation was adopted. Second, an aggressive export promotion program was enacted. Here a subsidies scheme - the so-called CATs - and the government export promotion office (Proexpo) played an important role. And third, imports were greatly liberalized; in 1983 the average tariff in Colombia was only 298, while the proportion of imports subject to QRs had greatly declined since 1967. As a consequence of these policies the Colombian non-coffee exports sector has performed in an efficient way, helping Colombia sustain a vigorous growth rate during the last 20 years. 25 In fact, today Colombia stands alone among the Latin American nations as a country that escaped the debt traumatic experience of the crisis while being able to maintain a reasonable rate of growth.

Although the evidence supporting the merits of outward orientation is abundant, there is no well developed theoretical model -. or empirical evidence for that matter -- linking very low (or zero) import tariffs to higher growth. 26 Nor is there evidence suggesting that a completely "hands. off" policy on behalf of the government is the most desirable alternative. In fact, the success of the East Asian countries with export led growth suggests that some selectively determined degree of intervention .. specially aimed at supporting exports . played a key role. 27 In this section no attempt will be made to solve the difficult and very important question of the optimal degree of government intervention, or of the optimal level and structure of import tariffs. This is indeed one of the most difficult question of economic policy, whose answer (even at the pure abstract and theoretical level) will depend on the existence of other distortions, the completeness of markets and the availability of other policy 
tools, among other things. Instead we will proceed under the assumption that in most of the highly indebted countries the current structure of imports protection is higher than the (unknown) optimal level and that, in the long run, these countries will gain from engaging in some trade liberalization aimed at reducing and uniforming import tariffs. Under these (very plausible) assumptions, in the rest of this section we will discuss specific issues dealing with the appropriate speed and sequencing of the trade liberalization component of an outward oriented strategy.

\section{III.2 Trade Liberalization With a Government Budget Constraint}

An important policy question is whether the trade liberalization component of an outward oriented strategy should be attempted at the same time as a country is embarked on a severe stabilization and anti-inflationary program. Not surprisingly, the answer depends on the intensity of the trade reform and of the ongoing inflation.

Historically, there has been a close link between mild trade liberali. zations and stabilization programs. ${ }^{28}$ Consider the following typical scenario leading to a stabilization program coupled with a mild to medium trade liberalization effort: ${ }^{29}$ at some point in time the authorities of a particular country decide to pursue a fiscal policy that is inconsistent with the chosen nominal exchange rate regime -. usually a pegged rate. Given the underdeveloped nature of the domestic capital market, the fiscal expansion is basically financed with domestic credit creation. As a result, there will be a loss of international reserves; domestic inflation will exceed world inflation, and the real exchange rate will become increasingly overvalued. In an effort to stop the drainage of reserves the authorities will usually respond by imposing exchange controls and by increasing the degree of restrictiveness of the existing trade impediments - - tariffs will 
be hiked and QRs will be imposed. Naturally, as long as the ultimate causes of the macroeconomic disequilibrium -. that is, the inconsistent credit and fiscal policies - are not tackled, all the authorities will gain by impos. ing new trade restrictions is delay the need for corrective macroeconomic measures. The real exchange rate will become more overvalued, international reserves will continue to decline, and a black market for foreign exchange will emerge. At some point this disequilibrium situation will become unsustainable, and a stabilization program -. usually under the aegis of the IMF - - will be enacted. This program will usually consist of a significant nominal devaluation geared at correcting the overvaluation developed in the previous period, of a contractionary macroeconomic policy, and of a liberalization of trade restrictions aimed at dismantling those controls imposed during the expansionary phase of the process. These types of trade liberalizations have historically been mild and have seldom consisted of complete elimination of QRs and major tariff reductions of the kind now recommended for the indebted countries. 30

Table 13 contains a summary on the evolution of trade exchange and capital controls in the period immediately following the adoption of 14 major Latin American stabilization episodes. In determining the timing of these programs, the implementation of the major nominal devaluation was taken as defining the beginning of the program. As may be seen, in many countries there were mild, and sometimes short lived, liberalizations; out of these 14 episodes we don't find a single major liberalization attempt. Perhaps Chile during 1975-1981 constitutes the most notable case of a major liberalization undertaken in conjunction with a major stabilization effort. The trade liberalization that eventually eliminated all QRs and reduced tariffs to a uniform $10 \%$ level was pursued at the same time as 
inflation was being reduced from 4008 to $108 .^{31}$ The Chilean episode illustrates very vividly one of the most serious trade-offs that emerges when a major liberalization is undertaken at the same time as a major antiinflation program. As in most successful stabilization programs, in the last phase of the Chilean stabilization effort .. when inflation was reduced from 40 to 9 per annum - there was a significant real exchange rate appreciation that reduced the degree of competitiveness of the tradables sector at a time when, due to the trade reform, among other factors, the equilibrium real exchange rate had significantly depreciated. In the Chilean case this real appreciation was partially the result of the active use of exchange rate management to bring down inflation; in mid 1979 the nominal exchange rate was fixed relative to the dollar. As is well known by now this real appreciation played an important role in the disappointing outcome of the Chilean episode; it seriously deprotected the tradables sector, it generated perverse expectations of devaluation and, ultimately, it conspired with the high real interest rates to provoke the worst financial debacle of Chilean history (Edwards and Cox-Edwards, 1987).

A crucial objective of any stabilization program - - and, as pointed out in Section II, indeed of those undertaken by the major debtors - - is to reduce the magnitude of the fiscal deficit. Many times there will be an important trade-off between a trade liberalization that reduces import tariffs and the achievement of this fiscal objective. Surprisingly, the policy and theoretical literatures on trade liberalization policies have most times tended to ignore the fiscal role of tariffs in the developing nations. Most theoretical and policy discussions on trade liberalization assume, along the lines of traditional trade theory, that tariff proceeds are handed back to the public. In reality, however, things are very 
different, with governments using tariff proceeds to finance their expenditure. This is particularly the case in many of the poorer developing countries where for different institutional reasons taxes on international trade represent a high percentage of government revenue. Table 14, for example, contains data on the fiscal importance of taxes on international trade for 8 countries. As maybe seen, taxes on trade are as high as $1 / 3$ of total revenue of the central government.

As long as tariff rates are below the maximum revenue tariff, there will be a trade-off between trade liberalization and the generation of the government surplus required to finance debt servicing. While the reduction of tariffs will generally reduce distortions, it will also have a negative effect on government finances. What is required, then, is to replace trade restrictions by less distortive taxes that can generate the same (or a higher) amount of revenue. This, of course, means that major reforms of the tax system would be required in most countries. As long as this tax reform effort also focuses on efficlency aspects, it will tend to be concentrated on the imposition of a value added tax (VAT), among other taxes. This is not easy and takes time, as a number of efforts to implement sweeping tax reforms have recently shown. Tax reforms are not only politically difficult to have approved, but from an administrative perspective it is many times very difficult to get them going. This is particularly the case in the poorer countries where the pre-existing tax system is many times very rudimentary. Indeed the recent Indonesian tax reform has very clearly shown the difficulties involved in these types of efforts. (See Conrad and Gillis, 1984). However, in middle income countries where there is an operating tax system of some sophistication a major tax reform can be implemented with some speed. The Chilean tax reform of 1975 is, in that sense, a good 
example; in little over a year a major tax overhaul that introduced a VAT, full indexation and unification of corporate and non-corporate tax rates was successfully implemented (Corbo, 1985).

Although in most cases the implementation of a major tax reform will take a substantial amount of time, there are some policies conducive both towards improved efficiency and higher revenues in the short run. The most obvious one is the replacement of QRs, (1.e., licenses, prohibitions and so on) by import tariffs. A well known feature of QRs is that unless they are auctioned, the government misses the revenue associated with the trade restriction. By replacing the $Q R$ by a tariff it is possible for the government to recapture this revenue.

The replacement of QRs by tariffs has two other potentlally desireable effects. First, there is a potential for a positive effect on income distribution. This is because in most cases large (or even multinational) firms or large established merchants get the import licenses and, thus, the rents. By replacing the QRs by tariffs these rents are passed on to the government, allowing it to reduce other taxes, or even increasing expenditure on social programs. Second, the replacement of tariffs by QRs, will generally increase the effectiveness of devaluations. The reason is that the effects of devaluations are significantly different under quantity rationing (1.e., import quotas or licenses) than under import tariffs. In the latter case a (real) devaluation will result in a higher price of both importables and exportables relative to nontradables. Under QRs, however, while the domestic price of exportables will still increase, that of importables will usually not be affected. All the devaluation will do is reduce the rents received by the party that got the license. 
A potential problem with the replacement of QRs by tariffs is that it Is not easy to decide on the tariff level that should be imposed instead of the QR, since under a number of plausible conditions (domestic monopoly being perhaps the most common) tariffs and quotas will not be equivalent. In this case there is no tariff that will exactly replicate both the domestic price and quantity resulting from the $Q R$. One possible alternative policy that has been used with some success in a few countries is to auction the quotas rather than allocating them in an arbitrary way. 32 Some of the attractive features of this option are the fact that it is possible to maintain the certainty on the volume imported, while at the same time the government captures back the rent associated with the quota allocation.

To sum up, in many countries -. and in particular in the poorer ones, with rudimentary tax systems - - taxes on trade are a very important source of government revenue. This introduces an important tradeoff between trade liberalization reforms and the maintenance (or achievement) of fiscal balance. In terms of the sequencing of reform, then, an important principle is to make sure that tariff reduction reforms should only be undertaken once the fiscal sector has been reformed and other sources of revenue have been found. 33 Replacing $Q R$ 's by tariffs, or devising a QRs auctioning system are measures that can be implemented without producing fiscal costs, while at the same time they improve efficiency. Also, by solving the fiscal imbalance first, the possibility of real exchange rate overvaluation is reduced.

\section{3 Tariff Reform and Unemployment}

The effects of trade reform on employment are a key consideration when evaluating the short-run effects of these policies. This is particularly the case under the current conditions, where countries are already 
experiencing very high levels of unemployment. Moreover, from a political economy perspective the unemployment effects of any policy are crucial; democratic governments -. and even those not so democratic, but in a weakened position -- will try not to generate massive unemployment: the costs of unemployment are recognized in the short run, while the benefits of the structural policies that provoked it usually are reaped in the medium run, when a different government is in office.

According to the simplest textbook approach, in a small developing economy with capital intensive imports, fully mobile factors of production, and flexible prices, the reduction of import tariffs will have no effect on total employment even in the short run. In this simple set up the only labor market effects of trade liberalization will be a reallocation of labor out of importables and an increase in the real wage rate. However, in reality there are a number of reasons why these textbook conditions don't hold, and why tariff reforms can result in a decline of employment in the short run.

The Ricardo-Viner model with downward real wages inflexibility provides the simplest model for illustrating the possible short run unemployment effects of a tariff reform. In this model capital is, in the short run, fixed to its sector of origin; only slowly through time (and possibly via investment) can capital be reallocated. Contrary to the more traditional textbook case with full flexibility of prices and resource movements, in this more realistic model a tariff reduction can result in a reduction of the equilibrium real wage rate required to maintain full employment. 34 However, if for some reason such as government imposed minimum wages, indexation or staggered contracts there is downward inflexibility of real wages, the required reduction in the wage rate will not take place, and 
unemployment will result. (See Edwards $1987 \mathrm{~b}$ for a formal exposition on how this model works in a world with importables, exportables and nontradables.) This unemployment, however, will only be of a short-run nature. As capital moves out of the importables sector and into the exportables and nontradable sectors, there will be forces working for the equilibrium real wage to increase, and those workers previously laid off will be rehired. A requirement for real wages to increase and for unemployment to disappear in the longer run is that capital is indeed reallocated. However, if - as has been the case very often with liberalization episodes - - the reform lacks credibility, capital will not be reallocated and unemployment will persist (Edwards 1986).

A shortcoming of the version of the Ricardo-Viner model discussed above is that it assumes economy-wide real wage inflexibility and no initial unemployment. In fact, in most developing countries minimum or inflexible wages don't cover all sectors, and usually apply to the urban sector only. In that regard, a more satisfactory model can be built using a three goods open economy version of the well known Harris-Todaro model with short run sector specific capital. (Throughout we maintain the very realistic assumption that importables are the most capital intensive, while nontradables are the most labor intensive goods.) Assume that while the importables (1.e., manufacturing) sector is subject to a minimum wage (in real terms), in the exportables and nontradables sectors there is wage flexibility. Initial equilibrium will be characterized by a positive amount of unemployment, that will generate an equalization between the real wage in the exportables and nontradables sectors and the expected real wage in the importable (manufacturing) sector covered by the minimum wage. Under our assumptions the post tariff reform short run equilibrium (with capital still fixed to its sector 
of origin) will be characterized by: (i) lower employment in the sector covered by the minimum wage (importables); (ii) lower wages in the uncovered sector, expressed in terms of exportables; (iii) either higher or lower equilibrium unemployment; (iv) either lower or higher employment in nontradables; (v) higher employment and production of exportables. (See Edwards $1987 b$ for a detailed analysis.)

Not surprisingly this case of partial minimum wage coverage generates very different results than the case of an economy wide minimum wage discussed above. First, we now have an increase in production and employment in exportables. Second it is possible that under our partial coverage case employment in nontradables will also increase. Also, in this case a tariff reduction reform may generate smaller unemployment in the short run, whereas in the case of an economy wide minimum wage greater unemployment always resulted in the short run as a consequence of a decline in the tariff (see Edwards $1987 \mathrm{~b}$ for detalled discussion).

These models suggest that, contrary to the most simplistic textbook view, as long as it takes time to reallocate capital from one sector to the other and (real) wages are inflexible, a tariff reduction reform may very well result in unemployment. A first best solution to this problem is to (fully) eliminate the sources of real wage rigidity; with complete flexibility wages will, in the short run, go down until all the labor force is absorbed. However, if for political or other reasons real wages cannot fall sufficiently, a second best solution is to proceed slowly with the trade reform; tariffs should be reduced gradually in a preannounced fashion. In theory, in this way capital owners will have time to reallocate capital, avoiding the unemployment effects of the trade reform. (See the Edwards 1987b.) Once again, for this solution to work, capital allocation should, 
in fact, respond to the announcement of reform; that is, the reform should be credible. ${ }^{35}$ (See section III.5 below.)

The NBER multicountry study on trade regimes and employment directed by Anne Krueger (1983) has provided ample evidence suggesting that countries that have followed outward-oriented policies have generally had a better employment record - both in terms of employment creation and lower unemployment rates over the long run - - than those nations that have adopted import substitution industrialization strategies. This study, however, refer to the long run characteristics and performance of the labor markets and don't say much about the aggregate employment effects during the transition immediately following a tariff reform.

The limited existing evidence on the short run aggregate employment consequences of trade liberalization indicates that in the case of mild reforms there have not been significant aggregate unemployment effects. This, indeed, would seem to be one of the preliminary conclusions of the exhaustive cross country study undertaken at the World Bank and directed by Michaely, Choksi and Papageorgiou (1986). It is, however, somewhat difficult to interpret the evidence from this massive investigation. For example, the episodes analyzed many times refer to exceedingly mild liberalizations - - for example, the 1970 Turkish devaluation, included in the study, would barely qualify as even a very timid liberalization. Also, from these studies, it is not possible to know in a precise way whether specific changes in aggregate employment respond to the trade reform, or if they are the result of other policies. This is the case, for example, of the slight increases in aggregate unemployment observed after a number of trade reforms, including the Turkish liberalization of 1980; the Korean reform of 1979-80; the Philippines' liberalization of 1981, and Israeli 
reform of $1972-1977$.

Once again the Chllean experience, with its textbook-type policies is educational. As already mentioned, between 1974 and 1979 Chile underwent one of the most, if not the most, ambitious trade liberalization of the modern time: quantitative restrictions were fully eliminated, a multiple exchange rate system consisting of up to 15 different exchange rates was unified, and tariffs were slashed to a uniform 10\%. During this same period unemployment in Chile was very high, reaching more than $20 \%$ in 1975 and never falling below 158. A subject extensively debated in Chile's popular media, as well as in the specialized press, is the extent to which the process of tariff reduction "contributed" to the unemployment problem. There is little doubt that as a result of the tariff reform a number of contracting, and even disappearing manufacturing firms lald off large numbers of workers. On the other hand, expanding firms from the exporting sectors increased employment, partially offsetting the negative effect. The net result, however, was an increase in unemployment generated by the trade reform. This negative effect was particularly marked in manufacturing where firms worked their way out of the difficult situation created by increased foreign competition by trimming their payrolls and increasing productivity (Edwards and Edwards, 1987).

There were two main ways in which the tariff liberalization generated short-run unemployment in Chile. First, there was a natural adjustment period where laid off workers took time to start searching for work in a different, expanding, sector. Second, the fact that in reality - contrary to the simplest textbook case - physical capital is fixed in its sector of origin made the expansion of production in a number of the exporting sectors somewhat sluggish at first. Only as additional investment took place 
through time was it possible to fully increase production and employment in these expanding sectors. However, the existence of wage rigidity and in particular of a minimum wage in real terms made the absorption of labor by the expanding industries more difficult. ${ }^{36}$ It is argued in Edwards (1985) that a slower reform would have resulted in a reduced unemployment effect. The proportion of total unemployment that can be attributed to the tariff reform is, however, relatively small when compared to the magnitude of the overall unemployment problem. Edwards (1985), for example, calculated that an upper bound for the unemployment effects of the trade reform was 3.5 percentage points of the labor force, or 129,000 people, with the bulk of this unemployment located in the food, beverages, tobacco, textiles and leather products subsectors (57,000 people). More recently, de la Cuadra and Hacette (1986) have calculated that the trade reform generated a reduction of employment in the manufacturing sector of approximately 50,000 workers. Even though these are not negligible numbers, they clear indicate that an explanation for the bulk of the Chilean unemployment should be sought elsewhere.

The above discussion has concentrated on the possible beneficial effects of a gradual trade reform on employment. However, there are other channels, mainly via an intertemporal effect on expenditure, through which a gradual tariff reform can have positive effects on the economy. For example, a slow reduction of tariffs will generally have a positive impact on the savings rate and on the current account. To the extent that the gradual trade liberalization process is a credible proposition, it will have a nontrivial effect towards reducing the consumption rate of interest. As the public expects tariffs, and thus the domestic price of importables, to be lower in the future it will postpone current consumption. Consequently 
savings will increase and the current account will improve.

In sum, a gradual lowering of tariffs offers a number of attractive features for economies such as the debt ridden countries. First, this strategy is likely to reduce the short-run unemployment consequences of the trade reform. Second, there will likely be positive effects on savings, helping growth prospects. Third, it will tend to improve the current account. And finally, a gradual reduction of tariffs will have positive effects on the government budget. On the negative side a gradual trade reform may lack credibility, in which case it may even induce perverse responses (see Section III.5).

\section{III.4. Structural Adjustment and Devaluation}

Nominal devaluations are an important component of most stabilization programs, and as discussed in Section II they have played a central role in the adjustment efforts following the debt crisis. The purpose of these nominal devaluations is to generate a real exchange rate adjustment, that would revert the real appreciation that most times precedes the balance of payments crisis. In turn, by improving the degree of domestic competitiveness and raising the domestic price of tradables the real devaluations are supposed to improve the external sector accounts of the country in question. Historically, however, when implementing stepwise discrete nominal

devaluations, many developing nations have found it difficult to sustain the real devaluations for a long period; in a high number of cases after some time - usually ranging from one to two years .. the real exchange rate effect of the nominal discrete devaluation has been fully eroded. In almost every instance this erosion can be traced back to the failure to implement consistent macroeconomic policies alongside the devaluations (see Edwards, forthcoming). 
Devaluations have also played a key role in the trade reform component of structural adjustment programs. It is generally accepted in policy circles that in order for a tariff reform to be successful, it has to be accompanied. if not preceded. by a real devaluation (see, however, Edwards for a critical evaluation of this proposition). The argument usually given is based on a partial equilibrium interpretation of the elasticities approach to exchange rate determination, and runs along the following lines: a lower tariff will reduce the domestic price of importables, and consequently increase the demand for imports. This, in turn, will generate an external imbalance (i.e., a trade account deficit), which assuming that the Marshall-Lerner condition holds, will require a (real) devaluation to restore equilibrium. This view is clearly captured by the following quote from Balassa (1982, p. 16): "[E]liminating protective measures would necessitate a devaluation in order to offset the resulting deficit in the balance of payments." It is along these lines, then, that the proponents of major liberalizations by the debt ridden countries have insisted that these tariff reductions should be accompanied by significant nominal devaluations (Balassa, et. al., 1986).

The "required" amount of devaluation will depend on a number of factors, including the initial conditions, the extent of the trade reform, the magnitude of the disequilibrium gap to be closed and the accompanying macroeconomic policies. ${ }^{37}$ In addition, and perhaps more importantly, the required devaluation will also depend on the speed at which the trade reform is implemented. Since, for a number of reasons including the short-run fixity of capital, short run supply elasticities are much lower than long run elasticities, under most circumstances a rapid trade reform will necessitate a higher real devaluation to maintain external equilibrium, 38 
Until quite recently mose traditional structural adjustment programs in the developing nations have contemplated discreet nominal devaluations where the official nominal exchange rate is abruptly adjusted by a fairly large percentage. More recently, however, more and more countries are opting for the adopiion of some sort of crawling peg after the devaluation. In a recent study on 18 devaluation episodes in Latin America, Edwards (1987) found that those countries that had adopted a crawling peg had been significantly more successful in sustaining a real depreciation than the discrete devaluers. This, of course, is not in itself surprising, since the crawlers maintained their real devaluation targets by "fighting off" the real exchange rate erosion with additional nominal devaluations in the following years. Typically, under this type of regime, after the initial exchange rate adjustment the authorities further devalue the currency in magnitudes approximately equal to the domestic rate of inflation. Of course, a potential problem with this policy is that it can lead to an explosive (nonconvergent) process, where the devaluation generates inflation, which partially erodes the real effect of the devaluation; this leads to a higher devaluation and even higher inflation and so on, ad-infinitum. This possible unstable path could happen in those countries where the structural macroeconomic disequilibrium - - and in particular the fiscal deficit . have not been corrected to a significant extent. An alternative scenario is one where macroeconomic equilibrium is attained and the process is stabilized at some mild rate of inflation, as in Chile in the recent period and in Colombia since 1967. The cited study by Edwards indicates that among the Latin American crawlers in Bolivia (1982), Peru (1975) and Mexico (1982) the higher real exchange rate was sustained at the cost of substantial permanent increase in the rate of inflation. 
In splte of the prominent role of devaluations in conventional adjustment programs, very little work has investigated empirically the effects of devaluations on the real level of economic activity or on income distribution. A recently revived strand of literature has argued that although devaluations may have a positive effect on the external accounts, they will achieve this at the cost of significant reductions in real activity. This is the so-called contractionary devaluation hypothesis. Edwards (forthcoming), has analyzed in detail the behavior of a large number of key economic variables during 39 devaluation episodes in developing countries. In this study the evolution of some key variables during the period going from 3 years prior to the devaluation to 3 years after the devaluation was analyzed and compared to the behavior of the same variables for a control group of 24 nondevaluing countries. Table 15 provides a summary of the distribution of the rate of growth of real GDP for the devaluing countries and the control group. Notice that 3 years prior to the devaluation this distribution is very similar to that of the control group. In fact, using a Chi-square test for homogeneity we are unable to reject the null hypothesis that these data come from the same distribution $\left(x^{2}(2)-0.046\right)$. Things, however, are very different as we approach the devaluation. Already during the two years prior to the devaluation we can see a significant difference between the devaluing and control groups, with the former exhibiting substantially lower levels of growth in every quartile. The Chi-square test strongly rejects the null hypothesis of homogeneity for the year of the devaluation $\left(x^{2}(2)=7.02\right)$ and all three years following devaluation. Notice, however, that in the years following devaluation a fairly fast recovery in the rate of growth of real GDP is detected. Although the information presented in this table is quite revealing, it does not allow us to know 
whether this behavior of real GDP growth is caused by devaluation or if it is the result of some of the policies preceding the devaluation. This problem can be partially avoided by using regression analysis. The following result was obtained using instrumental variables on a variance component model of 12 countries for 1965-1980:

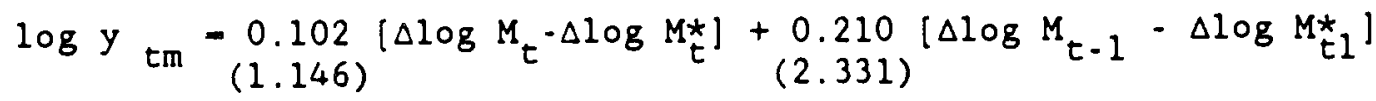

$$
\begin{aligned}
& +\underset{(3.023)}{0.112 \log (G E / Y)} t_{t}-\underset{(2.103)}{0.083} \log e_{t}+\underset{(2.086)}{0.069} \log e_{t-1} \\
& +0.044 \log \tau_{t}-0.008 \log { }^{\top} t-1 \quad \bar{R}^{2}=0.998 \\
& (1.431) \quad t(-0.265) \quad \mathrm{SEE}=0.038
\end{aligned}
$$

where $y$ is real output, $\left[\Delta \log M-\Delta \log M^{*}\right]$ is the unexpected rate of growth of money, $(G E / Y)$ is the ratio of government expenditure to GNP, e is the real exchange rate and $\tau$ is the terms of trade. According to these results then, in the short-run devaluation have led to a slight fall in output: a ten percent depreciation leads to a once off loss of almost one percent of GNP. In the second year, the economy returns to trend. 39

Income distribution data are very scarce in the developing countries. This undoubtedly explains, at least partially, why there have practically been no studies on the effects of devaluations on income distribution. However, there is little doubt that income and wealth distribution considerations enter heavily in the decisions of what kind of policies to implement. In Table 16 we present, as an illustration, some very preliminary data on devaluation and income distribution in 23 developing nations. This table contains the ratio of labor compensations to GDP for a period that goes from 4 years prior to a major devaluation to 3 years after the devaluations. The first column in the table provides information on the year of the devaluation. Although the ratio of workers compensations is a 
very rudimentary measure of income distribution, and this type of "before" and "after" methodology has well known shortcomings, these data are quite revealing. They confirm that in some instances devaluations have been followed by major worsenings in income distribution (i.e., Peru 1975). This trend, however, cannot be found in all cases, and not even in the majority of episodes. In fact, in a number of them the ratio of labor compensation increased following the devaluation. More than anything, however, these data indicate that in order to have a full understanding of the income distribution consequences of devaluations, it is necessary to look at more detailed data and at alternative categories, including the effect of devaluations on the rural-urban distribution of income.

To sum up then, the discussion in this section reveals once again, the existence of important trade-offs associated with the different goals of the adjustment program. While devaluation will generally have a positive effect on the external sector, helping generate the necessary excess supply for tradables, and easing the transition following a trade liberalization, it will have a negative impact on the cost of foreign exchange to the government, and on real GDP growth. In addition, devaluation will usually have important effects on income distribution and on inflation. Since the magnitude of "required" (real) devaluations will be closely related to the speed at which structural reforms are implemented, this discussion points out, once more, towards the desirability of proceeding gradually both on the debt payment and structural reforms format.

\section{III.5 Credibility. Sustainability and Reversibility of Trade Reforms} Credibility is a fundamental ingredient of successful structural reforms. If the public attaches a nontrivial probability to policy reversal, it will try to anticipate this event, generally introducing strong 
destabilizing forces into the structural adjustment process.

Latin America's history is replete with frustrated economic reforms that have failed due to the lack of credibility. In that respect, the frustrated Argentinian trade reform during the Martinez de Hoz period is very educational. Due to the lack of credibility on the future of the preannounced trade reform, firms used foreign funds in order to survive in the short run. As Carlos Rodriguez (1983: 28) has put it in his evaluation of the Argentina experience of 1978-82,

As a consequence of the lack of credibility on the continuity of the economic program, many firms - - which would have disappeared due to the tariff reductions -. decided to get into debt in order to remain operating while waiting for a change in the economic strategy lemphasis added] .

A fundamental aspect of establishing credibility is related to the perception that the public has of the internal consistency of the policies being pursued. In that respect, for example, the inconsistency of the Argentinian fiscal policy - - which maintained a very large deficit - - and the preannounced exchange rate policy severely undermined the degree of credibility of the reform process. In the case of Chile the markedly overvalued currency in 1981 was seen by large segments of the public as inconsistent with the long-run viability of the liberalized economy. In general, if the real exchange rate experiences an unprecedented real appreciation, the public will think that exports will not be able to develop and that there is a nontrivial probability of the reform's being reversed in the future. Under these circumstances it will be optimal for consumers to get into debt today in order to acquire "cheap" importables. 
The inability to establish consistency between fiscal and exchange rate policies has many times been at the heart of the trade reform credibility crises in Latin America. For example, in most cases where (mild) trade reforms have been reversed, the public early on perceived that the inflation tax required to finance the fiscal deficit was inconsistont with maintaining a predetermined nominal exchange rate. Under these circumstances expectations of overvaluation, speculative attacks, exchange controls and future devaluations developed. In trying to anticipate these events the optimizing private sector will usually take steps - - such as diversifying its portfolio internationally (i.e., "capital flight") - that will some times move the economy in the opposite direction from that intended by the reform. Edwards (1987) has found that in more than 808 of reversals of trade liberalizations in Latin America can be traced to inconsistent fiscal policies.

An important question is whether a gradual (i.e., slow) trade reform will be less or more credible than an abrupt one. Theoretical models of credibility of economic policy are only now being developed, and have not yet reached a level that enables us to answer this question with enough precision. ${ }^{40}$ In principle, it is possible to argue that gradualism has characteristics that work in both directions, at the same enhancing and compromising credibility. On one hand by reducing the unemployment effect, and by allowing for a firmer flscal equilibrium, a gradual trade reform will tend to be more credible; on the other hand a slow reform will allow those groups negatively affected by it (i.e., the import substitution manufactur. ing sector) to organize and lobby against the policies. At the end, as is so often the case in economics, whether gradualism will enhance credibility will depend on factors specific to each country. What is clear, however, is that policymakers should always pay special attention on the establishment 
of credibility when persuing important long term structural changes.

Given our knowledge of the policymaking process and its interaction with the private sector, it is not possible to derive a precise theorem at this point. However, the arguments presented in this section - including unemployment, fiscal and other considerations -- suggest that, in general, implementing the trade reform component of an outward orientation policy in a gradual way is more likely to be successful than an abrupt liberalization.

\section{Concluding Remarks and Summary}

The adjustment packages of 1982-87 sought "effectiveness". On some grounds - - and especially in terms of the turnarounds of the current accounts - the results have been quite impressive. The costs, however, have been high. Not only did real income decline, as illustrated in Table 2 , but real wages declined in most countries, and unemployment soared. There is little doubt that this is not a sustainable adjustment path. A successful adjustment means that debtor countries will have to bring down their debt to GDP ratios to a level consistent with the reestablishment of creditworthiness, while recovering their growth of output and consumption. The first objective means that the country has to transfer a given discounted value of resources to the rest of the world. The second means that the country has to increase its rate of capital formation and the efficiency of resource use. The problem faced by the highly indebted nations can be posed as follows: how to minimize the present value of foregone consumption of making a transfer of a specific discounted value. The problem has then two dimensions: how to minimize the cost of the transfer at each moment of time - including its distributive aspect - - and second an intertemporal one, i.e., what should be the flow of transfers over time 
consistent with a given present value of the flow.

The speed with which the transfer to the rest of the world is made will affect the (discounted value) of the cost of achieving creditworthiness. A very fast increase in the trade surplus can only be obtained at a very high cost in terms of nontraded goods and losses in unemployment, both because it takes time for factors to be retrained and to move, and because of wage inflexibility in the short-run. It also takes time to implement efficient fiscal instruments to generate the fiscal surplus, particularly if one wants to eliminate the present reliance of taxes on trade and the inflationary finance of the deficit. Finally, improving the allocation of investment and promoting the return of capital flight may involve liberalizing financial markets, which will increase the fiscal cost of servicing internal debt. Thus, improved efficiency and capital accumulation will require important increases in non-distortive taxes and cuts in public expenditures: but this takes time. In sum, there are important trade-offs between the speed of effecting the transfer and minimizing its cost at one moment of time. Instruments that help generate quickly the trade surplus - - like quantitative restrictions - - increase the resource cost of achieving the transfer. Instruments that quickly solve the fiscal problem -. like using tariffs or QRs instead of a devaluation - - also increase that cost.

A slower speed of the adjustment can only be achieved if the magnitude of the transfer countries have to make is reduced during the initial years. One way of achieving this is by providing these countries with additional lending during the transition. In principle this will allow the implementation of slower expenditure switching policies and the implementation of more efficient fiscal instruments to raise public resources. Most importantly, it will allow the investment rates to be kept up without unduly 
sacrificing consumption. Thus there is a complementarity between extra lending during the transition and the recovery of growth while transferring abroad a given present value of resources.

A longer run solution of the debt crisis will clearly require the adoption of policies that rely more heavily than in the past on export growth. Even ECLA/CEPAL, the former champion of import substitution development, has recommended outward oriented policies. Export promotion requires some kind of trade liberalization and tariff reduction -especially of imported inputs and capital goods. Indeed, the historical evidence clearly shows that those countries that have pursued successfully export promotion (i.e., the East Asian nations), have had a trade regime substantially more liberal than those countries that have followed indiscriminatory import substitution based on protectionism. A crucial question, however, is how much trade liberalization is needed. It is argued in the paper that although outward orientation requires some trade liberalization, there are no reasons -- either theoretical or empirical .that suggest that the "optimal" degree of liberalization implies zero, or even very low, tariffs coupled with no government intervention in any sphere of the development process. The successful experiences with export led growth in the East Asian countries support this view; although in these countries the trade regime has been significantly liberal, government intervention has been important and tariffs have never been anything close to zero or a very low (i.e., 10-158) uniform level.

An important policy question is whether the trade liberalization component of an outward oriented strategy should be attempted at the same time as a country is embarked on a severe stabilization program. The experience of the Southern Cone suggests that undertaking substantial trade 
reforms at the same time as a major anti-inflationary program is unlikely to be successful. This is both for fiscal and real exchange rate reasons. However, there are some measures, such as the replacement of quotas for tariffs, that can help both the anti-inflation drive as well as the quest for improvement of efficiency.

Under the most plausible circumstances a fast trade liberalization will generate short-run unemployment effects. Indeed, the empirical evidence from the Southern Cone tends to confirm this presumption. Trade liberalization will be more successful if it is gradual and preannounced. This, however, brings up serious credibility issues. Only if the announced gradual trade reform is "credible" will economic agents react as expected by the authorities. The analysis of devaluations presented in section III clearly suggests that under many circumstances abrupt devaluations can generate nontrivial short run costs in the form of output reductions and unemployment. Gradual liberalizations will require smaller devaluations, possibly reducing the associated costs.

A sustained increase in the indebted countries exports - which is, of course, a prerequisite for a long term solution to the crisis - - will not only require an efficient tradables sector and a "realistic" real exchange rate but, more important, that the current protectionist trend in the industrial countries and in particular in the.U.S. is reversed. Data presented in Edwards (1987a) indicate that at this time the extent of nontariff barriers, as a form of protection in the industrial countries, is very significant. Moreover, the data show that these trade impediments are particularly important for goods originating in the developing nations, and that their tariff equivalents are in many cases very significant. Asking the highly indebted developing countries to pay their debts at the same time 
as impeding their exports to reach the industrialized markets is asking for the impossible. 


\section{FOOTNOTES}

* Presented at the National Bureau of Economic Research Conference on Developing Countries Debt; Washington, DC, September 21-23, 1987. I have benefited from discussions with Marcelo Selowsky. I am grateful to Alejandra Cox-Edwards, Edgardo Barandiaran, Pari Kasliwal, Miguel Savastano, Jeff Sachs and to the participants of the pre-conference meeting held in Cambridge in May 1987 for helpful comments. Financial support from UCLA's Academic Senate and from the National Science Foundation is gratefully acknowledged.

1. It should be noticed, however, that most experts now agree that in some of the poorer countries it will be highly implausible to reduce the debtexport ratio to levels required to have access to new voluntary financing. In these cases some innovative and less orthodox solutions, including debt forgiveness, may be the most efficient way out.

2. See, for example, Balassa et. al. (1986) and Krueger (1987).

3. The IMF's 15 highly indebted countries are: Argentina, Bolivia, Brazil, Chile, Colombia, Cote d'Ivoire, Ecuador, Mexico, Morocco, Nigeria, Peru, Philippines, Uruguay, Venezuela and Yugoslavia.

4. On the Brazilian experience see Cardoso and Fishlow (1987); on Mexico see Buffie and Sanguines (1987); Celasun and Rodrick (1987) deal with Turkey; on Ch1le see Edwards and Edwards (1987).

5. See Dornbusch (this volume) for discussion of the role of the developed countries' macropolicies on the development of the crisis.

6. See Bianchi, Devlin and Ramos (1986).

7. Notice, however, that it is not completely rigorous to talk about overvalued real exchange rates without first analyzing the way in which the 
equilibrium real exchange rate has evolved (see Edwards, forthcoming). In the case of the debtor countries, however, the existing evidence clearly suggests that significant overvaluations developed.

8. On the Chilean experience see Edwards (1985) and Edwards and Edwards (1987)

9. On Argentina see Calvo (1986) and Corbo, de Melo and Tybout (1986). 10. On Colombia see Thomas (1986). See Collins and Park (1987) on Korea and Woo and Nasution (1987) on Indonesia.

11. The exact time periods are Argentina 1982-85, Ecuador 1982-83, Mexico 1983-84, Uruguay 1982-84 and Venezuela 1982-83.

12. Computed from raw data published in Government Finance Statistics Yearbook, 1986.

13. See Edwards and Edwards (1987).

14. Although real devaluations will increase the real domestic currency of servicing the public debts, they can have some other positive effects on the public sector's budget. This will be the case in those countries where the main exporting firms are government owned.

15. On the Argentinian exchange rate guarantees scheme see Calvo (1986); on Chile see Edwards (1985).

16. For a detailed analysis on the non-equivalence between quotas and tariffs see Bhagwati (1978). See also Hillman, Tower and Fishelson (1980). 17. Note, however, that in spite of Khan and Knight's description in the past not every Fund sponsored program included exchange rate actions. It is in fact important to recognize that historically the IMF has exhibited significantly more flexibility than what its critics have given it credit for. There has been, to some extent, a case-by-case approach. From the record it seems, however, that the Fund staff considers that the vast 
majority of the cases are quite similar.

18. Balassa et al. (1987) and Krueger (1987) are good representatives of this view. See also Fischer (1987).

19. The other policies advocated by Balassa et al. (1986) include financial reform, stable real exchange rates and a much reduced role for the government.

20. On the evidence on the performance of outward-vs. inward-oriented strategies see, for example, the World Bank 1987 World Development Report and the literature cited therein. On CEPAL see, for example, Bianchi et. al. (1987).

21. See Krueger (1978) and Bhagwati (1978). On earlier discussions on liberalization see little et. al. (1971). For a recent treatment of many of these issues see the volume edited by Choksi and Papageorgiou (1986). 22. This was indeed the meaning given by some to the concept during the Southern Cone experiences with market oriented policies in the late 1970 s and early 1980s. In a recent paper Bhagwati (1986) has made an effort to define in a precise way export promotion, import substitution, and ultra trade promoting trade policies. In the rest of this paper we will stick to trade and commercial policies when referring to trade liberalization. 23. See, for example, Bhagwati's (1986) recent splendid paper on outward orientation. To date the most impressive accumulation of empirical evidence supporting the better performance of outward orientation has been compiled in the 1987 World Development Report. See also Bhagwat1 and Srinivasan (1978).

24. See, for example, World Bank (1986).

25. On Colombia see Thomas (1986). 
26. Naturally, the welfare effects of trade liberalizations fall within the rest of second-best economics. Rigorously speaking if there are other distortions - as invariably there are in the real world -. it is not possible to know a priori if a partial trade liberalization w111 be welfare improving. If there are no other distortions, it is possible to establish a positive relation between the level of tariffs and the level of income. St11l however, no traditional growth model will link no tariffs to higher growth (see Lucas 1985).

27. Notice, however, that even the Koreans made mistakes when they pushed the government role too far. In that respect, the fiasco of 1974-79 when the government picked the wrong "winners" is well known. See World Bank (1986).

28. See, for example, Krueger (1981) and Little (1981).

29. See, for example, Edwards (1987a) for a detailed analysis of 18 stabilization cum mild liberalizations episodes in Latin America. 30. Naturally, although very common, this is not the only scenario leading to a stabilization-cum-structural adfustment program. In an alternative scenario, that fits some country's experiences during the period leading to the debt crisis, the fiscal expansion is financed with foreign borrowing instead of money creation. In this case the path leading to the need to adjust in not necessarily characterized by a piling up of trade and exchange controls.

31. The recent Bolivian experience is also characterized by a tremendous trade liberalization. However, the fact that this was part of a package to defeat hyperinflation sets the Bolivian case apart.

32. While a number of countries have successfully used foreign exchange auctions - - Jamaica, Sierra Leone, Uganda -- only a few have Implemented 
generalized auctions for imports of goods. See Krumn (1985) for a discussion on different experiences with exchange auctions.

33. Notice, however, that from a welfare perspective this is by no means a trivial proposition. Indeed, from a purely theoretical point of view it is not clear that reducing tariffs and increasing other taxes will be welfare improving. Moreover, at least at the theory level, it is not clear that welfare will increase if as liberalization advocates have sometimes proposed, consumption taxes are raised as tariffs are reduced. This, of course, is a simple application of the second best theorem.

34. Whether this reduction in the equilibrium real wage will actually take place will depend on the weight of exportables in the price level relevant for determining real wages. If, as in a large number of developing countries, exportables (i.e., foodstuffs) have a large weight in the consumer price index the equilibrium real wage will indeed decline. (See Edwards 1987b).

35. On theoretical models of labor market effects of trade reforms see Edwards $(1986,1987)$ and the references cited therein.

36. See Chapter 6 of Edwards and Edwards (1987) for a detailed discussion of the evolution of wages in Chile.

37. We are referring to the extent of real devaluation. However, since the real exchange rate is not a policy tool, economic authorities face the additional difficulty of deciding by how much to adjust the nominal exchange rate in order to generate a given real devaluation.

38. This statement assumes that a tariff reduction will result in an equilibrium real exchange rate depreciation. Although this is the more plausible case, theoretically it is not the only possible result. See Edwards (1987c). 
39. The countries included in this regression are: Brazil, Colombia, El Salvador, Greece, India, Israel, Malaysia, Philippines, South Africa, Sri Lanka, Thailand and Yugoslavia. For detalls, see Edwards (1986).

40. Guillermo Calvo, however, has recently made important contributions to this key area of the theory of economic policy (see Calvo 1986, 1987). 
REFERENCES

Balassa, B. 1982, Development Strategies in Semi-Industrial Countries

(Oxford: Oxford University Press).

, Bueno, G.M., Kuczynski, P.P. and Simeonsen, M.H., 1986 Toward

Renewed Economic Growth in Latin America, (Washington, DC: Institute of International Economics).

Bhagwati, J. 1978, Anatomy and Consequences of Exchange Control Regimes

(Cambridge, MA: Ballinger Publishing Co.) 1986, "Export Promoting Trade Strategies: Issues and Evidence,"

World Bank Discussion Paper UPERS7 and Srinivasan, T.N. 1978, "Trade Policy and Development," in R.

Dornbusch and J. Frenkel (eds.), International Economic Pollcy: Theory and Evidence (Baltimore: Johns Hopkins University Press).

Blanch1, A., Devlin, R., and Ramos, J. 1987, "The Adjustment Process in

Latin America, 1981-1986," paper presented at World Bank-IMF Symposium on Growth Orfented Adjustment Programs, Washington; D.C.

Buffie, E., and Sauguines, A. 1987, "Economic Policy and Foreign Debt in Mexico," unpublished NBER ms.

Calvo, G. 1986a, "Fractured Liberalism: Argentina Under Martinez de Hoz," Economic Development and Cultural Change, (April). 1986b, "Temporary Stabilization Predetermined Exchange Rates,"

Journal of Political Economy (December): 1319-1329. 1987, "Reform, Distortions and credibility," Working Paper, University of Pennsylvania.

Cardoso, E., and Fishlow, A. 1987, "The Macroeconomics of the Brazilian External Debt," unpublished NBER ms. 
Celasun, M. and Rodrik, D. 1987, "Debt, Adjustment Growth: Turkey 1970-85," unpublished NBER ms.

CEPAL 1986a, Panorama Economico de America Latina 1986 (Santiago Chile). 1986b, Balance Preliminer de la Economia Latino Americana 1986

(Santiago Chile).

Choski, A., and Papageorgiou, D. 1986 (eds.), Economic Liberalization in

Developing Countries, (Oxford: Blackwel1).

Collins, S. and Park, W.A. 1987, "External Debt, and Macroeconomic

Performance in Korea," unpublished NBER ms.

Conrad, R., and Gillis, M. 1984, "The Indonesian Tax Reform of 1983,"

Harvard Institute for International Development, Discussion Paper \#162.

Corbo, V., de Melo, J., and Tybout, J. 1986, "What Went Wrong in the

Southern Cone," Economic Development and Cultural Change (April).

Cuddington, J. 1986, Capital Flight: Estimates. Issues and Explanations

(Princeton, NJ: Princeton Studies in International Finance).

Cumby, R., and Levich, R. 1987, "On the Definition and Magnitude of Recent

Capital Flight," NBER Working Paper \#2275.

de la Cuadra, S., and Hachette, D. 1986, "The Timing and Sequencing of Trade

Liberalization Policy: The Case of Chile," unpublished ms, Catholic

University of Chile.

Diaz Alefandro, ?. 1963, Devaluation in a Semi-Industrial Country

(Cambridge, MA: MIT Press).

1984, "Good Bye Financial Repression, Hello Financial Crash,"

Journal of Development Economics.

Dornbusch, R. 1987a, "Debt Problems and the World Macroeconomy," this volune. 
1987b, "Our LDC Debts," forthcoming in M. Feldstein (ed.), The

U,S, in the World Economy (Chicago: University of Chicago Press).

Edwards, S. 1985, "Stabilization with Liberalization: An Evolution of the

Years of Chile's Experience With Free Market Policies, 1973-1983,"

Economic Development and Cultural Change (January).

1986, "Are Devaluations Contractionary?" Review of Economics and

Statistics (August).

1987a, Exchange Rate Misalignment in Developing Countries, NBER

Working Paper.

1987b, "Terms of Trade, Exchange Rates and Labor Market Adjust-

ments in Developing Countries," NBER Working Paper \#2481 forthcoming in

World Bank Economic Review.

1987c, "Tariffs, Terms of Trade and Real Exchange Rate in an

Intertemporal Model of the Current Account," NBER Working Paper \#2481.

1987d, "The U.S. and Foreign Competition in Latin America," NBER

Working Paper \#2544 forthcoming in M. Feldstein (ed.). The U.S, in the

World Economy (Chicago: University of Chicago Press).

1987d, "Exchange Controls, Devaluations and Real Exchange Rates:

The Latin American Experience," paper presented at Conference on Exchange

Controls, Bogota Colombia (June).

forthcoming, Real Exchange Rates, Devaluations and Adjustment

(Cambridge, MA: MIT Press).

and Cox-Edwards, A. 1987, Monetarism and Liberalization: The

Chilean Experiment (Cambridge, MA: Ballinger Publishing Co.)

Fischer, S. 1986, "Issues in Medium Term Macroeconomic Adjustment," World

Bank Research Observer (July). 
Hillman A., Tower, E., and Fishelson, F. 1980, "On Water in the Quota," Canadian Journal of Economics (May).

International Monetary Fund 1987, World Economic Outlook (April).

Khan, M., and Knight, M. 1985, Fund Supported Adjustment Programs and Economic Growth, (Washington, DC: IMF Occasional Paper No. 41). Krueger, A.0. 1978, Foreign Trade Reglmes and Economic Development: Liberalization Attempts and Consequences (Cambridge, MA: Ballinger Publishing Co.) 1981, "Interaction Between Inflation and Trade Regime Objectives in Stabilization Programs," in W. Cline and S. Weintraub (eds.), Economic Stabilization in Developing Countrles (Washington, DC: Brookings Institution).

1983, Trade and Employment in Developing Countries: Synthesis

and Conclusions (Chicago: University of Chicago Press). 1986, "Problems of Liberalization," in A. Choks 1 and D.

Papageorgious (eds.) Economic Liberalization in Developing Countries (Oxford: Blackwell). 1987, "The Problems of LDC Debt," paper presented at the NBER Conference on the U.S. In the World Economy, West Palm Beach.

Krumm, K. 1985, "Experiences with Foreign Exchange Rate Auctions," CPO

Working Paper (Washington, DC: The World Bank).

Little, Ian M.D. 1982, Economic Development (New York: Basic Books). , Scitovsky, T., and Scott, M. 1970, Industry and Trade in Some

Developing Countries (Oxford: Oxford University Press).

Lucas, R.E. 1985, "Economic Growth and Development," unpublished ms.

University of Chicago. 
Mckinnon, J. (1973), Money and Capital in Economic Development (Washington, DC: Brookings Institution). 1982, "The Order of Economic Liberalization: Lessons from Chile and Argentina," in K. Brunner and A. Meltzer (eds.), Economic Policy in a World of Change (Amsterdam: North-Holland).

Michaely, M., Papageorgiou, D., and Choksi, A. 19??, "The Phasing of a Trade Liberalization Policy: Preliminary Evidence," paper presented at AEA meeting, New Orleans.

Neary, P. 1978, "Dynamic Stability and the Theory of Factor-Market Distortions," American Economic Review, 671-682.

Ramos, J. 1986, Neoconservative Economics in the Southern Cone of South America (Baltimore: Johns Hopkins University Press).

Rodriguez, C.A. 1983, "Politicas de Estabilizacion en la Economia Argentina 1978-1982," Cuadernos de Economia (Apri1).

Sachs, J. 1986, "Managing the LDC Debt Crisis," Brookings Papers on Economic Activity. 1987. "Trade and Exchange Rate Policies in Growth Oriented Adjustment Programs," NBER Working Paper \#2226.

Selowski, M. and van der Tak, H. 1986, "The Debt Problem and Growth," World Development (September).

Thomas, V. 1986, Linking Macroeconomic and Agricultural Policies for Adjustment with Growth (Baltimore: Johns Hopkins University Press). Woo, W.T. and Nasution, A. 1987, "Indonesia Economic Policies and Their Relation to External Debt Management," unpublished ms. NBER. World Bank 1986, Korea: Managing the Industrial Transition (Washington, DC). 1976. World Development Report 1987 (Oxford: Oxford University Press). 


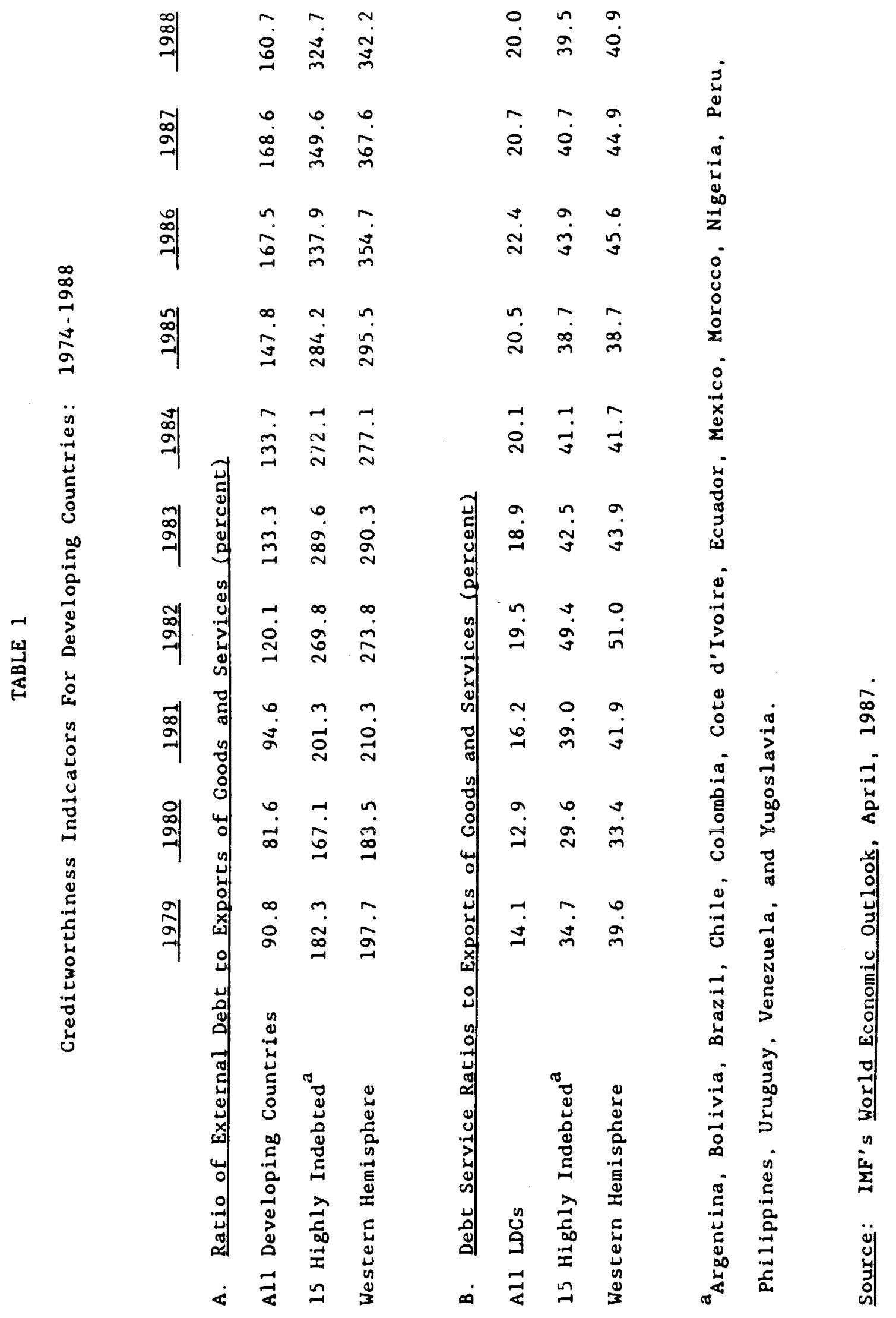


TABLE 2

Index of Real Gross Domestic Product Per Capita In Selected Latin American Countries

$(1970-100)$

Argentina

Bolivia

Brazil

Colombia

Chile

Mexico

Peru

Venezuela

$\begin{array}{rrrrrrrrr}1970 & 1975 & 1980 & 1981 & 1982 & 1983 & 1984 & 1985 & 1986 \\ 100 & 105.9 & 107.5 & 99.2 & 92.6 & 93.9 & 94.3 & 88.7 & 92.2 \\ 100 & 117.3 & 120.6 & 118.3 & 107.6 & 95.7 & 89.7 & 85.8 & 80.4 \\ 100 & 145.1 & 179.5 & 172.8 & 170.4 & 161.5 & 165.0 & 174.7 & 184.7 \\ 100 & 118.2 & 137.9 & 138.0 & 136.4 & 134.7 & 136.1 & 136.6 & 140.7 \\ 100 & 81.8 & 109.1 & 113.4 & 95.8 & 93.6 & 98.1 & 98.8 & 101.9 \\ 100 & 116.8 & 139.8 & 146.8 & 142.3 & 131.3 & 132.4 & 132.6 & 124.3 \\ 100 & 108.9 & 104.7 & 105.9 & 103.6 & 89.9 & 91.8 & 90.9 & 96.2 \\ 100 & 106.5 & 105.7 & 102.3 & 100.0 & 91.8 & 88.3 & 83.7 & 82.9\end{array}$

Source: CEPAL Anuario Estadistico de America Latina y el Caribe 1985 and CEPAL Balance Preliminar de la Economia Latinoamericana, 1986. 
TABLE 3

Estimates of Capital Flight in Selected Developing Countries *

$$
\text { (Billions U.S. \$) }
$$

$\begin{array}{lrrrrrr} & 1979 & \underline{1980} & \underline{1981} & \underline{1982} & \underline{1983} & \underline{1984} \\ \text { Argentina } & 2.2 & 3.5 & 4.5 & 7.6 & 1.3 & -3.4 \\ \text { Brazil } & 1.3 & 2.0 & -1.4 & 1.8 & 0.5 & 4.0 \\ \text { Korea } & -0.5 & -0.7 & -0.8 & 0.5 & -0.7 & -0.6 \\ \text { Mexico } & -1.1 & 2.2 & 2.6 & 4.7 & 9.3 & 2.6 \\ \text { Philippines } & 0.0 & -0.1 & 1.3 & 0.0 & -1.5 & -1.8 \\ \text { Venezuela } & 3.0 & 4.8 & 5.4 & 3.2 & 3.1 & 4.0\end{array}$

\footnotetext{
* These estimates use Wm. Cline's definition of capital flight as computed by Cumby and Levich.
}

Source: Cumby and Levich (1987). 


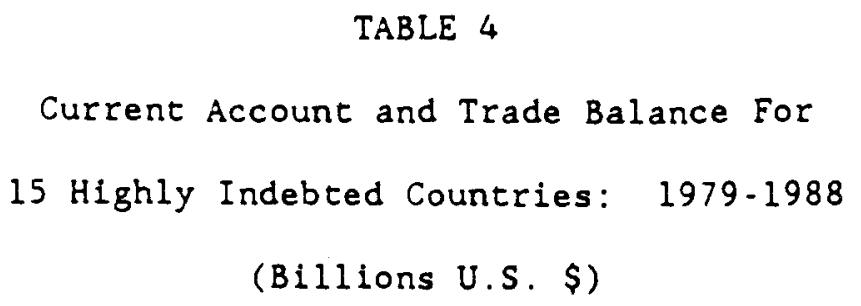

$\begin{array}{lrrrr}1979 & 94.2 & 96.1 & -1.9 & -24.6 \\ 1980 & 127.1 & 122.7 & 4.4 & -29.5 \\ 1981 & 126.1 & 133.6 & -7.5 & -50.3 \\ 1982 & 111.5 & 108.3 & 3.2 & -50.6 \\ 1983 & 111.1 & 82.8 & 28.3 & -15.2 \\ 1984 & 123.4 & 80.2 & 43.2 & -0.6 \\ 1985 & 119.2 & 78.4 & 40.8 & -0.1 \\ 1986 & 98.6 & 75.7 & 22.9 & -11.8 \\ 1987 & 101.5 & 83.3 & 18.8 & -14.0 \\ 1988 & 112.2 & 90.3 & 22.3 & -10.5\end{array}$

Source: IMF's World Economic Outlook (April 1987). 
TABLE 5

Capital Inflows and Net Transfer of Resources

in Latin America: $1976-1986$

(Billions of U.S. \$)

Year Net Capital Inflows Net Interest Payments Net Iransfer of Resources

$\left.\begin{array}{rrrr}1976 & 17.9 & 6.8 & 11.1 \\ 1977 & 17.2 & 8.2 & 9.0 \\ 1978 & 26.2 & 10.2 & 16.0 \\ 1979 & 29.1 & 13.6 & 15.5 \\ 1980 & 29.4 & 17.9 & 11.5 \\ 1981 & 37.5 & 27.1 & 10.4 \\ 1982 & 20.0 & 38.7 & -18.7 \\ 1983 & 3.2 & 34.3 & -31.2 \\ 1984 & 9.2 & 36.2 & -27.0 \\ 1985 & 2.4 & 35.3 & -32.9 \\ 1986 & 8.6 & 30.7 & -22.1\end{array}\right\} \overline{\mathrm{x}}-12.3$

Source: CEPAL, 1986, Table 14. 

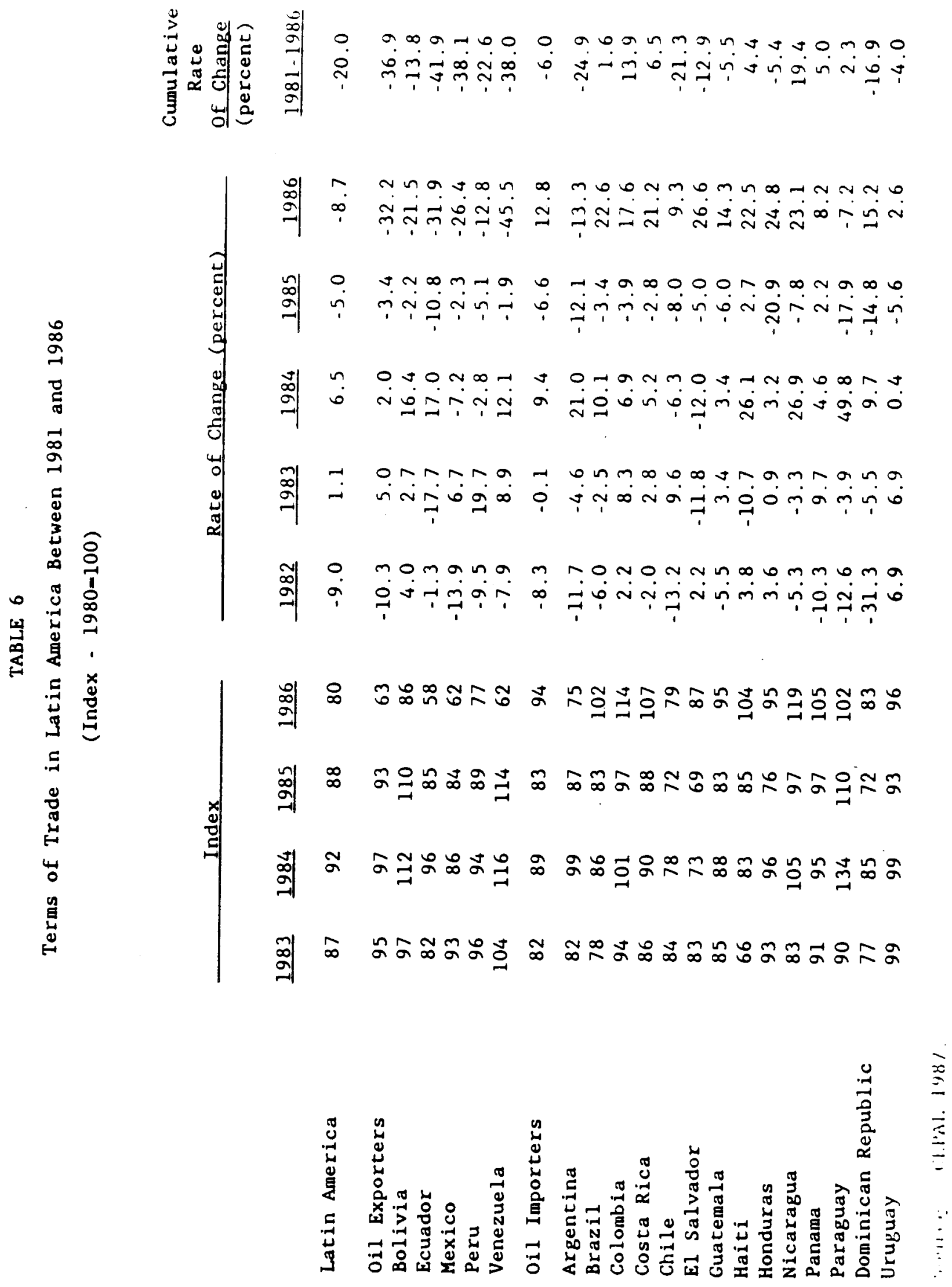
TABLE 7

Gross Investment as Percentage of GDP

In Selected Debtor Countries

(Percent)

Average 1975-80 1984

$\begin{array}{lll}\text { Argentina } & 25.2 & 17.8 \\ \text { Bolivia } & 29.5 & 28.5 \\ \text { Brazil } & 25.9 & 17.0^{\mathrm{a}} \\ \text { Chile } & 13.2 & 13.7 \\ \text { Cote d'Ivoire } & 26.5 & 22.1^{\mathrm{a}} \\ \text { Mexico } & 24.4 & 20.3^{\mathrm{a}} \\ \text { Nigeria } & 25.3 & 14.4 \\ \text { Peru } & 16.6 & 16.0 \\ \text { Philippines } & 30.1 & 17.1 \\ \text { Venezuela } & 34.3 & 16.0\end{array}$

$a_{1983 .}$

Source: International Monetary Fund. 
TABLE 8

Monetary Policy, Fiscal Policy and Inflation in Highly Indebted Countries

Central Government Annual Percentage Fiscal Deficits as Average Percentage

\begin{tabular}{|c|c|c|c|}
\hline Year & Change of Broad Money & Percentage of GDP & Change of $\mathrm{CPI}^{\mathrm{a}}$ \\
\hline 1979 & 51.8 & 0.8 & 40.8 \\
\hline 1980 & 55.2 & 0.8 & 47.4 \\
\hline 1981 & 64.0 & 3.7 & 53.2 \\
\hline 1982 & 69.3 & 5.4 & 57.7 \\
\hline 1983 & 86.7 & 5.2 & 90.8 \\
\hline 1984 & 117.7 & 3.1 & 116.4 \\
\hline 1985 & 125.4 & 2.7 & 126.9 \\
\hline 1986 & 73.9 & 4.5 & 76.2 \\
\hline 1987 & n.a. & 3.6 & 86.3 \\
\hline 1988 & n.a. & n.a. & 87.2 \\
\hline
\end{tabular}

average annual inflation for 1969.78 was 28.58 .

Source: International Monetary Fund. 
TABLE 9

Evolution of Real Wages in Selected Latin American Countries

(Percentage Variation)

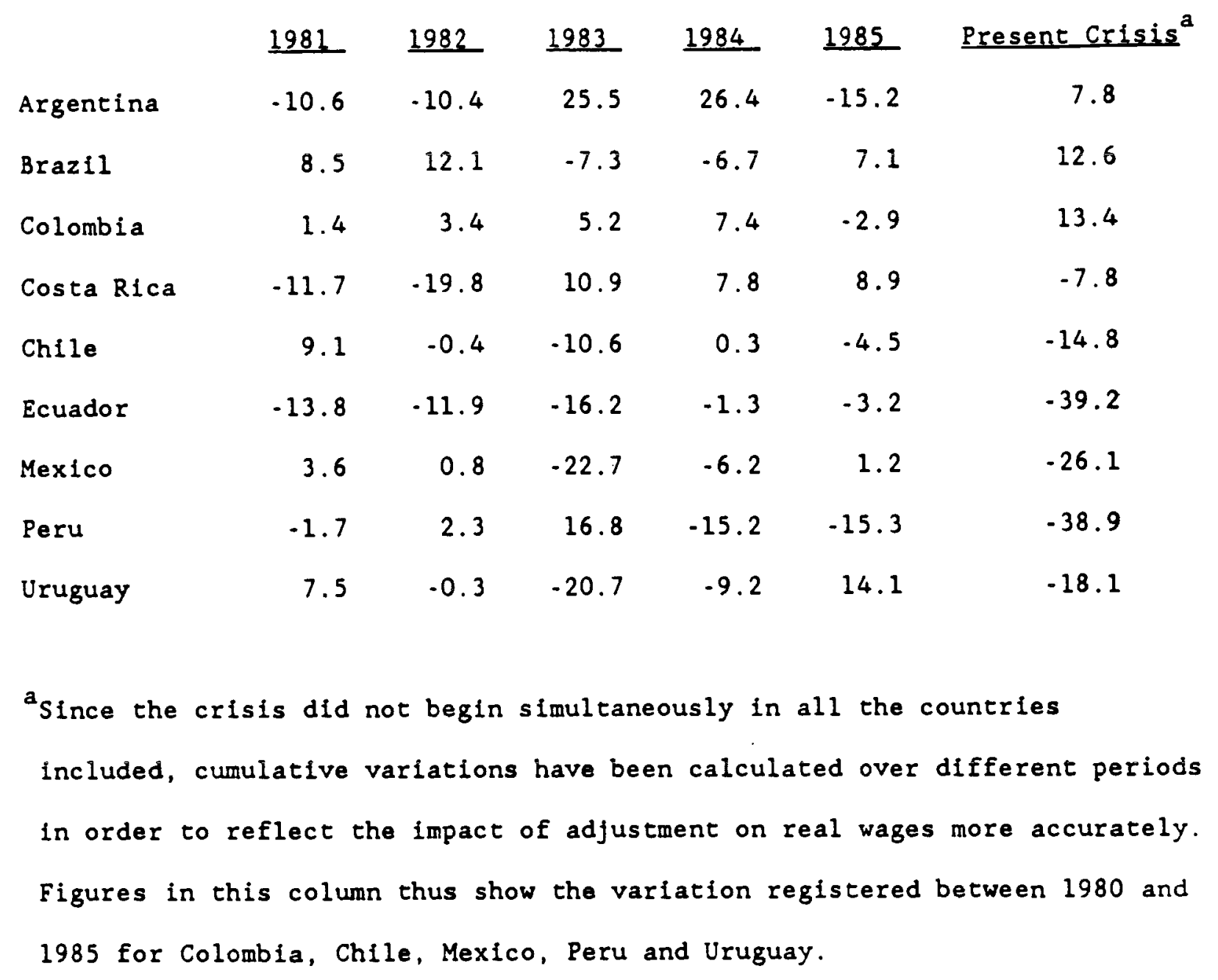

Source: CEPAL (1986). 
TABLE 10

Real Effective Exchange Rate Indices, 1980-100

(Trade Weight at 1980)

$\begin{array}{cccccccc}1 & \text { Argentina } & \text { Bolivia } & \text { Brazil } & \text { Chile } & \text { Mexico } & \text { Peru } & \text { Venezuela } \\ 1980 & 100.00 & 100.00 & 100.00 & 100.00 & 100.00 & 100.00 & 100.00 \\ 1981 & 99.11 & 79.75 & 84.06 & 85.52 & 87.97 & 85.77 & 89.00 \\ 1982 & 177.98 & 58.21 & 77.60 & 92.00 & 112.34 & 81.15 & 80.66 \\ 1983 & 188.62 & 71.15 & 91.10 & 115.91 & 132.97 & 85.59 & 75.51 \\ 1984 & 139.35 & 28.42 & 102.65 & 118.12 & 114.66 & 87.91 & 105.67 \\ 1985 & 173.78 & 9.5 & 103.85 & 145.52 & 106.22 & 101.91 & 104.81 \\ 1986 & 203.71 & 103.93 & 111.68 & 162.39 & 135.61 & 84.98 & 100.81\end{array}$

Note: An increase of this index indicates real devaluation, while a decline is a real appreciation. These real effective exchange rate indexes have been computed as trade welghted geometric average of the bilateral exchange rates adjusted by the ratio of domestic consumer price index to the corresponding trade partner wholesale price index. 


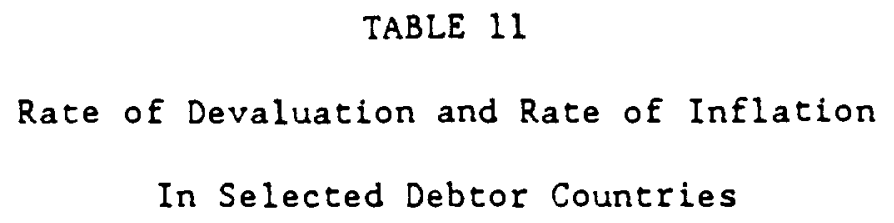

\footnotetext{
$a_{1982-1985 .}$
}

Source: International Financial Statistics. 
TABLE 12

\author{
Examples of Additional Trade Restrictions \\ During the 1982.86 Period
}

Mexico 1982: QRs were imposed on all imports (during the 1970-80 decade QRs only affected 60 percent of imports).

Argentina 1984: Decree 4070: All imports required a permit. All imports competing with local production are subject to authorization (with consultations to domestic producers' associations). 1985: Tariff surcharge of 10 percent over imports and 9 percent for exports.

Venezuela 1983: Foreign exchange controls and a two tier offlcial exchange rate system. QRs on 70 percent of final consumption goods.

Chile 1982: Import surcharges ranging from 4 to 288 imposed on more than 30 items. Alson, two tier exchange rate established. 1983: Import tariffs raised from 108 to uniform 208. 1984: Import tariffs temporarily hiked to 35 percent. 1985: The uniform import duty system is stabilized at 208 (from the earlier uniform level of 108).

Source: The World Bank 
TABLE 13

Summary of Evolution of Exchange Controls and

Trade Restrictions After Enactment of Stabilization

Programs in Selected Latin American Countries

\begin{tabular}{|c|c|c|c|c|}
\hline Country & Year & $\begin{array}{c}\text { Payments } \\
\text { Restrictions on } \\
\text { Current Transactions } \\
\end{array}$ & $\begin{array}{l}\quad \text { Tariffs, } \\
\text { Duties and Cost- } \\
\text { Related Measures }\end{array}$ & $\begin{array}{l}\text { Restrictions } \\
\text { on Capital } \\
\text { Transactions }\end{array}$ \\
\hline Argentina & 1970 & $\begin{array}{l}\text { - Decreasing restric- } \\
\text { tions for one year. } \\
\text { Then highly } \\
\text { restrictive. }\end{array}$ & $\begin{array}{l}\text { - Short run liber- } \\
\text { alization; abrupt } \\
\text { increase in } \\
\text { tariffs } 6 \text { mths. } \\
\text { after dev. }\end{array}$ & $\begin{array}{l}\text { - Increased } \\
\text { restrictiveness. }\end{array}$ \\
\hline Bolivia & 1972 & $\begin{array}{l}\text { - No significant } \\
\text { changes. }\end{array}$ & $\begin{array}{l}\text { - No change for } 1 \\
\text { yr. Rapid in- } \\
\text { crease in tariffs } \\
1 \text { yr. after. }\end{array}$ & - No change. \\
\hline Bolivia & 1979 & $\begin{array}{l}\text { - No significant } \\
\text { changes. }\end{array}$ & $\begin{array}{l}\text { - Mild liberaliza. } \\
\text { tion. }\end{array}$ & $\begin{array}{l}\text { Slight liberal- } \\
\text { ization of } \\
\text { capital movement } \\
\text { ceilings. }\end{array}$ \\
\hline Colombia & 1962 & - Decreasing. & $\begin{array}{l}\text { - Liberalization of } \\
\text { advanced deposits. }\end{array}$ & - No change. \\
\hline Colombia & 1965 & $\begin{array}{l}\text {-Short-lived } \\
\text { liberalization. }\end{array}$ & $\begin{array}{l}\text { - Short-lived lib- } \\
\text { eralization of } \\
\text { advanced deposits. }\end{array}$ & $\begin{array}{l}\text { - After } 14 \text { mths. } \\
\text { restrictions } \\
\text { greatly hiked. }\end{array}$ \\
\hline Costa Rica & 1974 & $\begin{array}{l}\text { - Very short run } \\
\text { liberalization. }\end{array}$ & $\begin{array}{l}\text { - Short run liber- } \\
\text { alization tariffs } \\
\text { were later raised. }\end{array}$ & $\begin{array}{l}\text { Restrictions on } \\
\text { capital flows } \\
\text { introduced. }\end{array}$ \\
\hline Ecuador & 1961 & - No clear pattern. & $\begin{array}{l}\text { - No change in } \\
\text { tariffs; increase } \\
\text { in advanced } \\
\text { deposits rates. }\end{array}$ & - No change. \\
\hline Ecuador & 1970 & $\begin{array}{l}\text { - Slight liberal- } \\
\text { ization. }\end{array}$ & $\begin{array}{l}\text { - Mild reduction in } \\
\text { tariffs; important } \\
\text { liberalization of } \\
\text { advanced deposits. }\end{array}$ & $\begin{array}{l}\text { - Mild liberal- } \\
\text { ization of } \\
\text { capital movement } \\
\text { restrictions. }\end{array}$ \\
\hline Nicaragua & 1979 & $\begin{array}{l}\text { Very slight } \\
\text { liberalization. }\end{array}$ & - No changes. & $\begin{array}{l}\text {-Very sharp } \\
\text { increase in } \\
\text { degree of } \\
\text { restrictions. }\end{array}$ \\
\hline
\end{tabular}


Table 13 (cont)

\begin{tabular}{|c|c|c|c|c|}
\hline Country & Year & $\begin{array}{c}\text { Payments } \\
\text { Restrictions on } \\
\text { Current Transactions }\end{array}$ & $\begin{array}{l}\text { Tariffs, } \\
\text { Duties and Cost- } \\
\text { Related Measures } \\
\end{array}$ & $\begin{array}{l}\text { Restrictions } \\
\text { on Capital } \\
\text { Transactions } \\
\end{array}$ \\
\hline Peru & 1967 & $\begin{array}{l}\text { - Increased restrict- } \\
\text { iveness. }\end{array}$ & - Tariffs raised. & $\begin{array}{l}\text { - Sharp increase } \\
\text { in restrictions. }\end{array}$ \\
\hline Venezuela & 1964 & $\begin{array}{l}\text { - Slight increase in } \\
\text { restrictiveness. }\end{array}$ & - No change. & - No change. \\
\hline Chile & 1982 & $\begin{array}{l}\text { - No changes for } 2 \\
\text { years. }\end{array}$ & $\begin{array}{l}\text { - Slight increase } \\
\text { in tariffs; no } \\
\text { advanced } \\
\text { deposits. }\end{array}$ & $\begin{array}{l}\text { - Slight reduction } \\
\text { and then } \\
\text { increase in } \\
\text { restrictions. }\end{array}$ \\
\hline Colombia & 1967 & $\begin{array}{l}\text { - Slow liberaliza- } \\
\text { tion. }\end{array}$ & $\begin{array}{l}\text { - Slow liberaliza- } \\
\text { tion. }\end{array}$ & $\begin{array}{l}\text { - Mild liberal- } \\
\text { ization. }\end{array}$ \\
\hline Peru & 1975 & $\begin{array}{l}\text { - No significant } \\
\text { change. }\end{array}$ & $\begin{array}{l}\text { - Increase in } \\
\text { tariffs levels. }\end{array}$ & $\begin{array}{l}\text { - Slight } \\
\text { liberalization. }\end{array}$ \\
\hline
\end{tabular}

Source: Constructed from information obtained from various issues of the IMF's Annual Report on Exchange Arrangements and Exchange

Restrictions and from various issues of Pick's Yearbook and World Currencies Yearbook. 
TABLE 14

Taxes on International Trade as a Percentage of

Government Revenue: Selected Developing Countries, 1984

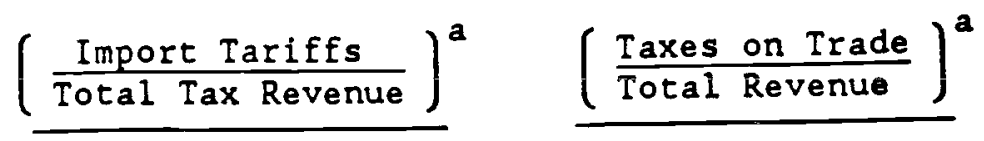

$\begin{array}{lcc}\text { Argentina } & 4.98 & 13.38 \\ \text { Bolivia } & 25.68 & 30.08 \\ \text { Chile } & 13.48 & 10.88 \\ \text { Indonesia } & 3.58 & 3.38 \\ \text { Korea } & 16.18 & 14.08 \\ \text { Philippines } & 22.18 & 23.78 \\ \text { Peru } & 10.28 & \mathrm{n} . \mathrm{a} . \\ \text { Mexico } & 3.08 & 2.78 \\ & & \\ & & \\ \text { a Refers to central government. } & & \\ \text { Source: } \quad \text { Gonstructed from raw data from the International Monetary Fund's } & \end{array}$


TABLE 15

Growth of Real GDP in Devaluing and Non Devaluing Countries

(Percent)

$$
\text { First }
$$

Quartile

A. 39 Devaluation Countries

$\begin{array}{ll}3 \text { Years Before } & 7.4 \\ 2 \text { Years Before } & 8.4 \\ 1 \text { Year Before } & 7.3 \\ \text { Year of Deval. } & 6.1 \\ 1 \text { Year After } & 6.4 \\ 2 \text { Years After } & 6.4 \\ 3 \text { Years After } & 9.2\end{array}$

B. Control Group of 29 Non Devaluing Countries

7.4

6.4

4.5

Source: Edwards (forthcoming). 
TABLE 16

Devaluations and Income Distribution

(percentage of compensation to employees with respect to GDP)

Year of

Devalua -

tion -4

$-4$
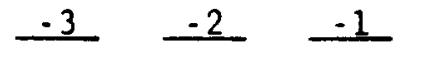

Dev. Yr.

Argentina

$1970 \quad 40$

41

$40 \quad 40$

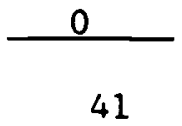

$+1+2$

$+3$

Bolivia

$\begin{array}{llll}1971 & 37 & 37 & 34\end{array}$

$34 \quad 36$

$\begin{array}{lllll}1979 & 33 & 34 & 35 & 35\end{array}$

n. a

35
36

42

39

43

$1982 \quad 35$

$36 \quad 36$

n.a.

32
36

$30 \quad 33$

40

Chile

$\begin{array}{lllll}1982 & 39 & 36 & 38 & 40\end{array}$

n.a.

n.a.

n.a.

n.a.

Colombia

1962 n.a. n.a. $34 \quad 36$

$1964 \quad 34$

$\begin{array}{lll}36 & 38 & 38\end{array}$

$\begin{array}{lllll}1965 & 36 & 38 & 38 & 36\end{array}$

38

n.a.

n.a.

n.a.

$37 \quad 36$

36

$48 \quad 48$

45

$\begin{array}{lll}87 & 88 & 87\end{array}$

$1067 \quad 87$

88

Ecuador

1961 n.a.

n.a.

n.a. 28

$\begin{array}{ll}1970 & 27 \\ 1982 & 28\end{array}$

27

28

$32 \quad 30$

Egypt ${ }^{2}$

1962 n.a.

n.a. $\quad 39 \quad 41$

197946

39

38

37

$47 \quad 48$

49

$72 \quad 74$

72

India

$1966 \quad 73$

89

89

89

Israe 1

1962 n.a. $1967 \quad 44$

n.a.

45

197150

46

44

48

44

44

50

47

$50 \quad 50 \quad 46$

Jamaica

$1967 \quad 50$

56

57

56

34

35

35

33

37

36

50

49

47

$\begin{array}{ll}1980 & 32 \\ 1967 & 49\end{array}$

so


Table 16 (cont.)

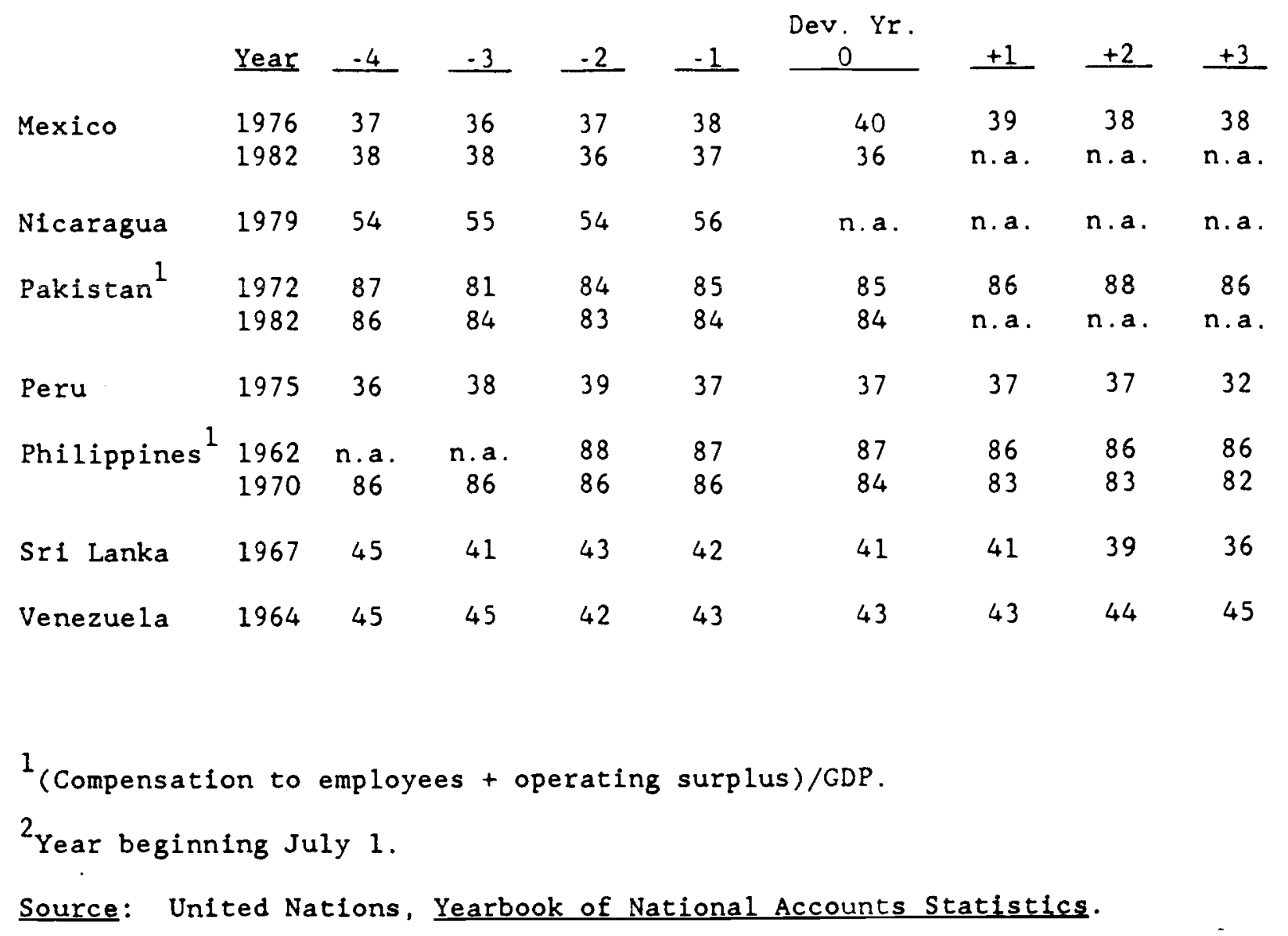

